\title{
Fuzzy multi-criteria decision making for carbon dioxide geological storage in Turkey
}

\author{
Muhammet Deveci $^{\mathrm{a}}{ }^{*}$, Nihan Çetin Demirel $^{\mathrm{a}}$, Robert John $^{\mathrm{b}}$, Ender Özcan $^{\mathrm{b}}$ \\ ${ }^{a}$ Department of Industrial Engineering, Faculty of Mechanical Engineering, University of Yildiz Technical, 34349 \\ Yildiz, Istanbul, Turkey \\ ${ }^{b}$ ASAP Research Group, School of Computer Science, University of Nottingham, NG8 1BB Nottingham, UK
}

\begin{abstract}
The problem of choosing the best location for $\mathrm{CO}_{2}$ storage is a crucial and challenging multicriteria decision problem for some companies. This study compares the performance of three fuzzy-based multi-criteria decision making (MCDM) methods, including Fuzzy TOPSIS, Fuzzy ELECTRE I and Fuzzy VIKOR for solving the carbon dioxide geological storage location selection problem in Turkey. The results show that MCDM approach is a useful tool for decision makers in the selection of potential sites for $\mathrm{CO}_{2}$ geological storage.
\end{abstract}

\section{Introduction}

According to the IEA World Energy Outlook (WEO) Reference Scenario, $\mathrm{CO}_{2}$ emission will increase $63 \%$ by 2030 from today's level, which is $90 \%$ higher than the $1990 \mathrm{CO}_{2}$ emission level. This is a global issue. Thus, stronger actions/policies are required and expected from the governments, including generation and utilization of certain technology options (IEA, 2004) to avoid massive $\mathrm{CO}_{2}$ emission increases. $\mathrm{CO}_{2}$ capture and storage (CCS) is a successful emission reduction option, which is used for capturing $\mathrm{CO}_{2}$ generated from fuel use and preventing pollution by storing it. Besides energy supply security benefits, this option has also numerous environmental, economic and social benefits (Blunt, 2010; Liao et al., 2014; Kissinger et al., 2014; IEA, 2004). CCS can make large reductions in greenhouse gas emissions, which involves capturing $\mathrm{CO}_{2}$ in deep geological formations (Davison, 2007). It is increasingly being considered as a significant greenhouse gas (GHG) mitigation option that allows continuity of the use of fossil fuels and provides time needed for deployment of the renewable energy sources at large scale (Ramirez et al., 2009).

*Corresponding author. Tel.: +90 212383 2865; fax: +90 2123833024 .

E-mail address: mdeveci@yildiz.edu.tr, muhammetdeveci@gmail.com (M. Deveci), nihan@yildiz.edu.tr (N.Ç. Demirel), robert.john@nottingham.ac.uk (R. John), ender.ozcan@nottingham.ac.uk (E. Özcan). 
$\mathrm{CO} 2$ can be stored underground in geological formations. Underground depleted reservoirs (depleted oil and gas reservoirs, aquifer reservoirs, salt cavern reservoirs, coal mine and mined cavern) are important types of underground $\mathrm{CO}_{2}$ storage (Sunjay and Singh, 2010). In some cases, underground storage has a commercial value. For example, the oil and gas companies have used $\mathrm{CO}_{2}$ extensively for three decades to improve oil recovery. Apart from this, $\mathrm{CO}_{2}$ can also be used for coal-bed methane recovery (Adams and Davison, 2007). Natural gas reservoirs, due to their proven record of gas production and integrity against gas escape, are obvious candidate sites for carbon sequestration by direct carbon dioxide $\left(\mathrm{CO}_{2}\right)$ injection (Sunjay and Singh, 2010). CCS is a method for distilling carbon dioxide and transporting it through pipelines and injecting it into available rock formations to prevent its emission to the atmosphere (Feron and Paterson, 2011; Stasa et al., 2013).

Even with energy efficiency and use of renewable energy resources it is predicted that the dependence on fossil fuels will continue. Despite the fact that in all combustion processes carbon dioxide is an output, it is not possible to get rid of carbon dioxide entirely.

This paper focuses on the $\mathrm{CO}_{2}$ storage issues in Turkey. Similar to many other countries in the world, the annual increase of $\mathrm{CO}_{2}$ emission in Turkey is quite high. The biggest $\mathrm{CO}_{2}$ site in this country is in the West Raman area. $\mathrm{CO}_{2}$ has been transferred through pipelines from the Dodan Area and injected into this site starting from 1985 (Sahin et al., 2012). Most of the real-world strategic decisions require consideration of many conflicting factors. Multi-criteria Decision Making (MCDM) techniques provide the means to solve such problems supporting decision makers with the best option from a set of alternatives with respect to those factors (Alpay, 2010). There are some previous studies proposing a variety of solution methods for finding the optimum location for $\mathrm{CO}_{2}$ storage (Kissinger et al., 2014; Ramirez et al., 2009; Stasa et al., 2013; Grataloup et al., 2009) and only a few of them are based on MCDM (Hsu et al., 2012; Llamas and Cienfuegos, 2012; Llamas and Camara, 2014).

In this study, we have designed and applied fuzzy-based MCDM approaches, including Fuzzy TOPSIS, Fuzzy ELECTRE I and Fuzzy VIKOR, comparing their performance to decide the best $\mathrm{CO}_{2}$ storage reservoir in Turkey, which has not been studied before. In fact, this problem can be solved by using any of these three methods, but given the importance of selection of storage location problem, the best alternative is searched by testing many techniques. Furthermore, the elasticity of these methods is also compared to each other.

The rest of the paper is organized as the following. Section 2, provides an overview of the relevant work. Section 3 discusses the location selection criteria for the $\mathrm{CO}_{2}$ storage and describes the Fuzzy TOPSIS, Fuzzy ELECTRE I and Fuzzy VIKOR methods. Section 4, presents a case 
study from Turkey and compares the performance of different fuzzy methods applied to this case study. Finally, Section 5 concludes this study.

\section{Related Work}

Although underground $\mathrm{CO}_{2}$ storage location selection problem is a crucial strategic decision this problem has not been addressed fully by others. On the other hand, there are plenty studies on a variety of facility location problems. Here we provide an overview of previous work. Grataloupa et al. (2009) studied on-site selection for $\mathrm{CO}_{2}$ underground storage in deep saline aquifers. As a case study, the proposed approach was applied to PICOREF, located in Paris Basin, where potential site(s) in deep saline aquifers were investigated. Kissinger et al. (2014) addressed different aspects while considering potential $\mathrm{CO}_{2}$ storage reservoirs, including safety and economical feasibility of each location. This work is based on the Gravitational Number applied to the North German Basin. Ramirez et al. (2010) presented a methodology to screen and rank Dutch reservoirs suitable for long-term large scale $\mathrm{CO}_{2}$ storage. The screening was focused on gas, oil and aquifers fields. In total 177 storage reservoirs were taken into consideration (139 gas fields, 4 oil fields and 34 aquifers) from over five hundred suitable locations. The total number of storage reservoirs were reduced by applying preconditions with associated threshold values. Then, linear aggregation was used for deciding on the location. Stasa et al. (2013) investigated into the potential of using principles of Darcy's law and numerical computing for $\mathrm{CO}_{2}$ capture and storage in Czech Republic.

In recent years, many papers on facility location problems have been published. Many of those previous studies propose multi-criteria decision making (MCDM) techniques as a solution method. Considering that multiple criteria with imperfect and uncertain factors are involved, fuzzy based methods, such as, TOPSIS, VIKOR and ELECTRE I, (Zadeh, 1965) are commonly utilised as approaches to such MCDM problems. An overview of previous work on relevant MCDM studies is provided in Table 1, which covers the MCDM solution methods, particularly focusing on analytic hierarchy/network process, fuzzy ELCTRE I, Fuzzy TOPSIS and Fuzzy VIKOR, applied to given location selection problems. Hsu et al. (2012) presented an analytic network process (ANP) approach for the selection of potential sites for $\mathrm{CO}_{2}$ geological storage. The results obtained in this study have proven that ANP-based approach is a useful tool in prescreening potential sites for $\mathrm{CO}_{2}$ geological storage. Llamas and Cienfuegos (2012) described a methodology for the selection of site areas or structures for $\mathrm{CO}_{2}$ geological storage based on an analytic hierarchy process (AHP). Ertugrul and Karakasoglu (2008) compared the fuzzy TOPSIS and fuzzy AHP methods for facility location selection. The proposed methods were applied to a 
facility location selection problem of a textile company in Turkey. The authors illustrated the similarities and differences of two methods. Demirel et al. (2010) proposed Choquet integral for multi-criteria warehouse location selection. This study provides a successful application of multicriteria Choquet integral to a real warehouse location selection problem for a large Turkish logistics firm. Kahraman et al. (2003) studied four different fuzzy multi-attribute group decisionmaking approaches, including fuzzy modelling of group decisions and fuzzy analytic hierarchy process. Although four approaches have the same objective of selecting the best facility location, each has a different theoretic basis and relate differently to the discipline of multi-attribute group decision-making. Opricovic (2011) presented a fuzzy VIKOR approach for a dam (water resources) location selection, providing a conceptual and operational validation of the approach on a real-world problem. Ozdagoglu (2011) proposed a fuzzy ANP approach to overcome the problem of facility location selection. Chou et al. (2008) integrated fuzzy set theory, factor rating system and simple additive weighting into fuzzy simple additive weighting system to select the facility locations. Zandi and Roghanian (2013) extended Fuzzy ELECTRE based on VIKOR method. The purpose of this paper is to extend ELECTRE I method based on VIKOR to rank a set of alternatives versus a set of criteria to show the decision maker's preferences. Chu (2002) presented a fuzzy TOPSIS model was developed in which ratings and weights of each alternative location can be aggregated by interval arithmetic and $\alpha$-cuts of fuzzy numbers. Ulukan and Kop (2009) used fuzzy TOPSIS method in a two step procedure. Firstly, candidate locations were defined by a trapezoidal membership function. Then, this trapezoidal numbers embedded into criteria and alternatives in TOPSIS. Finally, suitable facility location selected for the medical waste disposal company, able to handle the fuzziness of the real world. Tre et al. (2011) considered elementary Logic Scoring of Preference (LSP) suitability map criteria for evaluating a distribution of points of interests (POIs) in a geographical region.

Table 1

An overview of some previous studies on multi-criteria location selection problems.

\begin{tabular}{|l|l|c|c|c|c|c|}
\hline Author (Year) & Subject & $\begin{array}{c}\text { AHP/ } \\
\text { ANP }\end{array}$ & $\begin{array}{c}\text { Fuzzy } \\
\text { ELECTRE }\end{array}$ & $\begin{array}{c}\text { Fuzzy } \\
\text { TOPSIS }\end{array}$ & $\begin{array}{c}\text { Fuzzy } \\
\text { VIKOR }\end{array}$ & $\begin{array}{c}\text { Fuzzy } \\
\text { Choquet }\end{array}$ \\
\hline Ashrafzadeh et al. (2012) & $\begin{array}{l}\text { Warehouse location } \\
\text { selection }\end{array}$ & & & $\mathrm{x}$ & & \\
\hline $\begin{array}{l}\text { Choudhary and Shankar } \\
\text { (2012) }\end{array}$ & $\begin{array}{l}\text { Thermal power plant } \\
\text { location selection }\end{array}$ & $\mathrm{x}$ & & $\mathrm{x}$ & & \\
\hline Devi and Yadav (2013) & Plant location selection & & $\mathrm{x}$ & & & \\
\hline $\begin{array}{l}\text { Fetanat and Khorasaninejad } \\
\text { (2015) }\end{array}$ & Wind farm site selection & $\mathrm{x}$ & $\mathrm{x}$ & & & \\
\hline Hsu et al. (2012) & $\begin{array}{l}\mathrm{CO}_{2} \text { storage location } \\
\text { selection }\end{array}$ & $\mathrm{x}$ & & & & \\
\hline Hu et al. (2009) & $\begin{array}{l}\text { Distribution center } \\
\text { location selection } \\
\text { problem }\end{array}$ & & & $\mathrm{x}$ & & \\
\hline Ka (2011) & $\begin{array}{l}\text { Dry port location } \\
\text { selection }\end{array}$ & $\mathrm{x}$ & $\mathrm{x}$ & & & \\
\hline
\end{tabular}




\begin{tabular}{|l|l|c|c|c|c|c|} 
Kabir and Sumi (2014) & $\begin{array}{l}\text { Power substation } \\
\text { location selection }\end{array}$ & $\mathrm{x}$ & & & \\
\hline Kaboli et al. (2007) & Plant location selection & $\mathrm{x}$ & & & & \\
\hline $\begin{array}{l}\text { Llamas and Cienfuegos } \\
\text { (2012) }\end{array}$ & $\begin{array}{l}\mathrm{CO}_{2} \text { storage location } \\
\text { selection }\end{array}$ & $\mathrm{x}$ & & & & \\
\hline Llamas and Camara (2014) & $\begin{array}{l}\mathrm{CO}_{2} \text { storage location } \\
\text { selection }\end{array}$ & $\mathrm{x}$ & & & & \\
\hline Momeni et al. (2011) & Plant location selection & & & & $\mathrm{x}$ & \\
\hline Nazari et al. (2012) & Landfill site selection & $\mathrm{x}$ & & & & \\
\hline Panigrahi (2014) & $\begin{array}{l}\text { Thermal power plant site } \\
\text { selection }\end{array}$ & & & $\mathrm{x}$ & & \\
\hline Rezaei et al. (2013) & $\begin{array}{l}\text { Underground dam } \\
\text { selection }\end{array}$ & $\mathrm{x}$ & & & & \\
\hline Sanchez-Lozano et al. (2015) & $\begin{array}{l}\text { Solar thermoelectric } \\
\text { power plants location } \\
\text { selection }\end{array}$ & $\mathrm{x}$ & $\mathrm{x}$ & $\mathrm{x}$ & & \\
\hline Verma et al. (2010 & $\begin{array}{l}\text { Facility location } \\
\text { selection }\end{array}$ & & & $\mathrm{x}$ & & \\
\hline Wu et al. (2014) & $\begin{array}{l}\text { Thermal power plant } \\
\text { location selection }\end{array}$ & & & & & $\mathrm{x}$ \\
\hline Yong (2006) & Plant location selection & & & $\mathrm{x}$ & & \\
\hline
\end{tabular}

\section{Methodology}

The proposed methodology consists of three basic stages: (1) Identification of the criteria, alternatives and linguistic variables to be used in the model (2) Analysis of methods using these selected criteria, alternatives and linguistic variables (3) Ranking the alternatives using fuzzy TOPSIS, fuzzy VIKOR, and fuzzy ELECTRE I. The schematic diagram of the proposed methodology for the selection of $\mathrm{CO}_{2}$ storage location is shown in Fig. 1. The stages are as follows:

Stage 1: Form the fuzzy model using selected criteria, location alternatives and a team of decision makers. Also fuzzy weights of each criterion and alternative are computed.

Stage 2: Analyze different alternatives based on the relevant algorithmic framework.

Stage 3: Rank each alternative based on the outcome from Stage 2.

The steps of this methodology are constructed with inspiration by other studies in the literature. The primary logic of Fuzzy TOPSIS is the determination of positive ideal and negative ideal distances of the alternatives and according to that making a ranking between the alternatives. In Fuzzy ELECTRE I, concordance and discordance indices are used. In Fuzzy VIKOR method, maximum group benefit and minimum individual regret are taken into account for ranking the alternatives. Hence, the effect of each method's calculation technique on the problem can be seen. As a result, finding the best alternative is aimed with these MDCM techniques. 


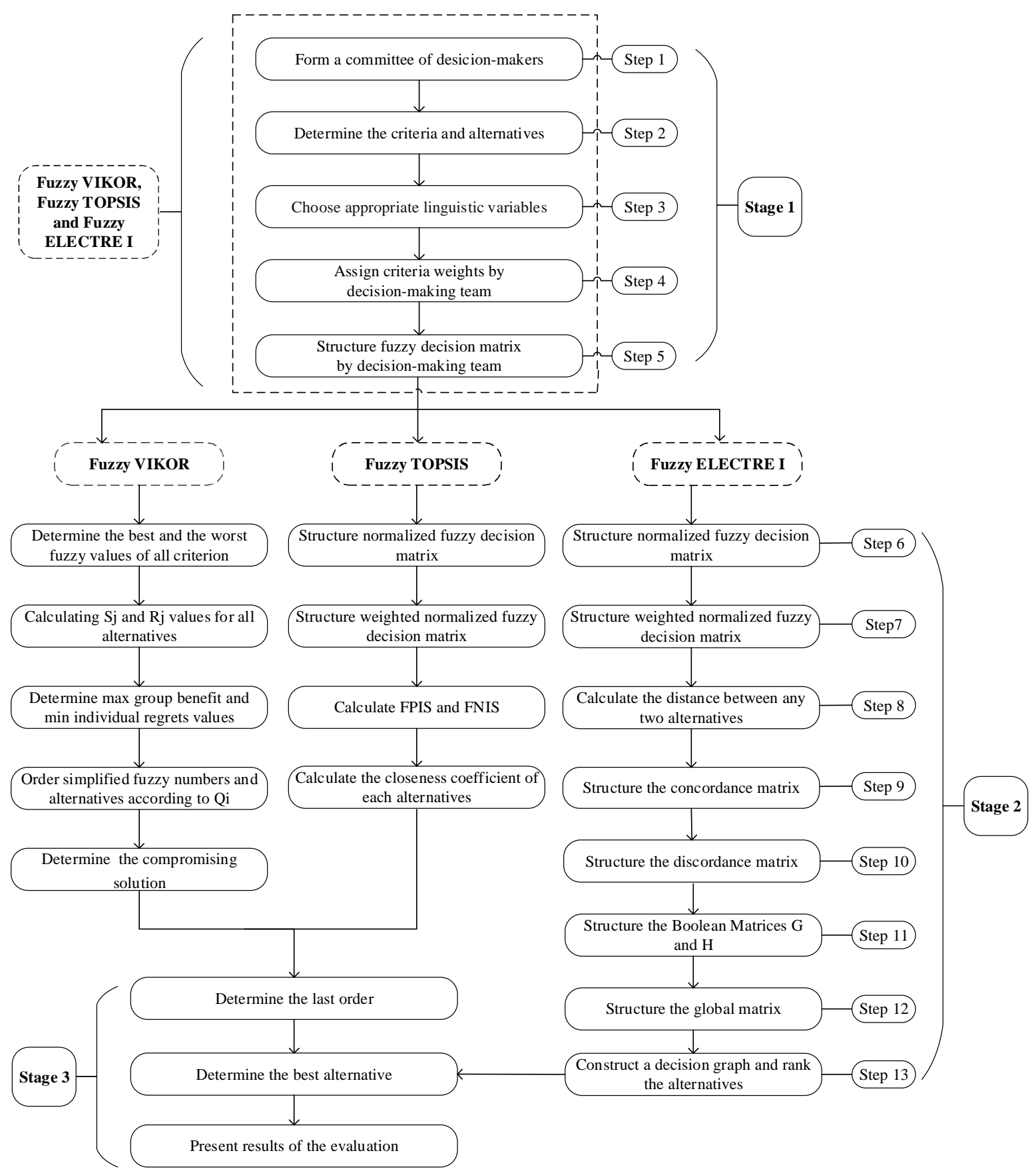

Fig. 1. Steps of Fuzzy VIKOR, Fuzzy TOPSIS and Fuzzy ELECTRE I for location selection.

\section{Criteria}

There is no consensus on the main criteria for the selection of $\mathrm{CO}_{2}$ storage location in the scientific literature. For example, Badri (1999) suggested that cost and legal restrictions determine the final decision on choosing the best storage location, while Ersoy (2011) confirmed that legal restrictions are relevant and additionally, proximity to suppliers/resources and 
infrastructure availability are extremely crucial criteria. In this study, we employ 12 different criteria identified and synthesized from the scientific literature. Each criterion is presented and explained in Table 2.

Table 2

Criteria and definitions.

\begin{tabular}{|c|c|c|c|}
\hline & Criteria & Definition & $\begin{array}{c}\text { Criteria } \\
\text { Type }\end{array}$ \\
\hline $\mathrm{C}_{1}$ : & Cost & $\begin{array}{l}\text { There are different types of cost. Initial cost for the } \\
\text { investment, transportation costs, maintenance costs, labor } \\
\text { costs, etc. }\end{array}$ & Cost \\
\hline $\mathrm{C}_{2}$ : & Storage capacity & The capacity of the underground geological formations & Benefit \\
\hline $\mathrm{C}_{3}$ : & Regional Risks & Risks in the region (like earthquake risk, natural risk, etc.) & Cost \\
\hline $\mathrm{C}_{4}$ : & Legal Restrictions & $\begin{array}{l}\text { Government regulations, environmental legislation and work } \\
\text { and health safety, bureaucracy. }\end{array}$ & Benefit \\
\hline $\mathrm{C}_{5}$ : & Environment and public & $\begin{array}{l}\text { Social acceptability, community attitudes, environmental } \\
\text { regulations. }\end{array}$ & Benefit \\
\hline $\mathrm{C}_{6}$ : & $\begin{array}{l}\text { Proximity to suppliers \& } \\
\text { resources }\end{array}$ & $\begin{array}{l}\text { Distance to roads, distance to powerline, accessibility of raw } \\
\text { materials }\end{array}$ & Benefit \\
\hline $\mathrm{C}_{7}$ : & Infrastructure availability & $\begin{array}{l}\text { Technological quality and availability of basic } \\
\text { infrastructure, pressure and flow systems. }\end{array}$ & Benefit \\
\hline $\mathrm{C}_{8}$ : & Reservoir area and net thickness & $\begin{array}{l}\text { The storage capacity potential in the geological field given } \\
\text { that the reservoir has a high net thickness. Because the net } \\
\text { thickness of reservoir formation provides opportunities for } \\
\mathrm{CO}_{2} \text {, it should be at a certain thickness (Hsu et al., 2012). }\end{array}$ & Benefit \\
\hline $\mathrm{C}_{9}$ : & Cap rock permeability and thickness & $\begin{array}{l}\mathrm{CO}_{2} \text { storage in the long term must necessitate cap rocks with } \\
\text { sufficient thickness for safe storage. The seal capacity of a } \\
\text { cap rock enabling successful sealing of the original } \\
\text { hydrocarbon in the reservoirs for a geological period } \\
\text { (Ramirez et al., 2010). }\end{array}$ & Benefit \\
\hline $\mathrm{C}_{10}$ : & Transportation availability & Quality of transportation and distribution infrastructure. & Benefit \\
\hline $\mathrm{C}_{11}$ : & Porosity & $\begin{array}{l}\text { Required to estimate the potential volume available for } \mathrm{CO} 2 \\
\text { sequestration in depleted oil and gas reservoirs (Hsu et al., } \\
\text { 2012). }\end{array}$ & Benefit \\
\hline $\mathrm{C}_{12}$ : & Sustainability & $\begin{array}{l}\text { Sustainability in the long term denotes the economic, social } \\
\text { and environmental viability of the storage. }\end{array}$ & Benefit \\
\hline
\end{tabular}

\subsection{Fuzzy TOPSIS Method}

The TOPSIS (Technique for Order Preference by Similarity To An Ideal Solution) method was proposed for the first time for multi-criteria decision-making problems in 1981 (Hwang and Yoon, 1981). This method determines the alternative closest to the positive ideal solution and the most distant to the negative ideal solution and makes a ranking accordingly (Chen, 2000). The logic behind this method is to make fuzzy assessments which are expressed linguistically and using the linguistic variables in the analysis. In this paper, the fuzzy TOPSIS method proposed by Chen (2000) and Chen et al. (2006), is used. The pseudo-code of this method is as follows: 
Step 1. Form a committee of decision-makers $(\mathrm{k}=1,2, \ldots, \mathrm{K})$.

Step 2. Determine criteria $(\mathrm{j}=1,2, \ldots, \mathrm{n})$ and alternatives $(\mathrm{i}=1,2, \ldots, \mathrm{m})$.

Step 3. Choose linguistic variables for evaluating criteria and alternatives. The proposed linguistic variables used for determining the criteria weights, significance degrees of the alternatives and the corresponding fuzzy numbers are provided in Table 3. In fuzzy set theory, scales are applied to convert the linguistic terms to fuzzy numbers. In multi-criteria decision making problems, fuzzy sets are used as a method to include the assessment of the decision makers under an uncertain environment. In this study, triangular fuzzy numbers are used. The triangular fuzzy number is represented as a triplet $\widetilde{\mathrm{X}}=(\mathrm{l}, \mathrm{m}, \mathrm{u})$.

Table 3

Linguistic variables and fuzzy numbers (Chen, 2000).

\begin{tabular}{|c|c|c|c|}
\hline \multicolumn{2}{|c|}{ Linguistic variables for the importance weight of each criterion } & \multicolumn{2}{|c|}{ Linguistic variables for the ratings } \\
\hline Linguistic variables & Membership function & Linguistic variables & $\begin{array}{l}\text { Membership } \\
\text { function }\end{array}$ \\
\hline Very low (VL) & $(0,0,0.1)$ & Very poor (VP) & $(0,0,1)$ \\
\hline Low (L) & $(0,0.1,0.3)$ & Poor $(\mathrm{P})$ & $(0,1,3)$ \\
\hline Medium low (ML) & $(0.1,0.3,0.5)$ & Medium poor (MP) & $(1,3,5)$ \\
\hline Medium (M) & $(0.3,0.5,0.7)$ & Fair $(F)$ & $(3,5,7)$ \\
\hline Medium high $(\mathrm{MH})$ & $(0.5,0.7,0.9)$ & Medium good (MG) & $(5,7,9)$ \\
\hline $\operatorname{High}(\mathrm{H})$ & $(0.7,0.9,1)$ & Good $(G)$ & $(7,9,10)$ \\
\hline Very high $(\mathrm{VH})$ & $(0.9,1,1)$ & Very good (VG) & $(9,10,10)$ \\
\hline
\end{tabular}

Step 4. Fuzzy weights for each criterion and alternative are calculated using the equations (1) and (2), where " $K$ " is the number of decision makers.

$$
\begin{array}{ll}
\widetilde{\mathrm{w}}_{\mathrm{j}}=\frac{1}{\mathrm{~K}}\left[\widetilde{\mathrm{w}}_{\mathrm{j}}^{1}(+) \widetilde{\mathrm{w}}_{\mathrm{j}}^{2}(+) \ldots(+) \widetilde{\mathrm{w}}_{\mathrm{j}}^{\mathrm{K}}\right], \quad \mathrm{j}=1,2, \ldots, \mathrm{n} \\
\tilde{\mathrm{x}}_{\mathrm{ij}}=\frac{1}{\mathrm{~K}}\left[\tilde{\mathrm{x}}_{\mathrm{ij}}^{1}(+) \tilde{\mathrm{x}}_{\mathrm{ij}}^{1}(+) \ldots(+) \tilde{\mathrm{x}}_{\mathrm{ij}}^{\mathrm{K}}\right], & \mathrm{i}=1,2, \ldots, \mathrm{m}
\end{array}
$$

$\widetilde{\mathrm{x}}_{\mathrm{ij}}$ is the degree of alternative I according criterion $\mathrm{j}$ and $\widetilde{\mathrm{w}}_{\mathrm{j}}$ is the significance weight of criterion $\mathrm{j}$ (where $\widetilde{\mathrm{w}}_{\mathrm{j}}^{\mathrm{k}}$ and $\widetilde{\mathrm{x}}_{\mathrm{ij}}^{\mathrm{k}}$ are the rating and the significance weight of the $k$ th decision maker).

Step 5. Structure the fuzzy decision matrix. The fuzzy decision matrix is created using the equations (3) and (4). The fuzzy decision matrix for the alternatives $(\widetilde{\mathrm{D}})$ and the criteria $(\widetilde{\mathrm{w}})$ are constructed as follows:

$$
\widetilde{\mathrm{D}}=\left[\begin{array}{cccc}
\tilde{x}_{11} & \tilde{x}_{12} & \cdots & \tilde{x}_{1 n} \\
\tilde{x}_{21} & \tilde{x}_{22} & \cdots & \tilde{x}_{2 n} \\
\vdots & \vdots & \vdots & \vdots \\
\tilde{x}_{m 1} & \tilde{x}_{m 2} & \cdots & \tilde{x}_{m n}
\end{array}\right] \quad \text { (3) } \quad \widetilde{\mathrm{w}}_{\mathrm{j}}=\left[\widetilde{\mathrm{w}}_{1}, \widetilde{\mathrm{w}}_{2}, \ldots \ldots, \widetilde{\mathrm{w}}_{\mathrm{n}}\right]
$$


where $\widetilde{\mathrm{x}}_{\mathrm{ij}} \forall \mathrm{i}, \mathrm{j}$ and $\widetilde{\mathrm{w}}_{\mathrm{j}} ; \mathrm{j}=1,2, \ldots ., \mathrm{n}$ (criteria) are the linguistic variables which can be described by triangular fuzzy numbers, $\tilde{x}_{i j}=\left(a_{i j}, b_{i j}, c_{i j}\right)$ and $\widetilde{w}_{j}=\left(w_{j 1}, w_{j 2}, w_{j 3}\right)$.

Step 6. Normalize the fuzzy decision matrix.

$\widetilde{R}=\left[\widetilde{r}_{i j}\right]_{m x n} \quad i=1,2, \ldots, m ; j=1,2, \ldots, n$

Where $\mathrm{B}$ and $\mathrm{C}$ are the set of benefit criteria and cost criteria, respectively:

$\tilde{r}_{i j}=\left(\frac{a_{i j}}{c_{j}^{*}}, \frac{b_{i j}}{c_{j}^{*}}, \frac{c_{i j}}{c_{j}^{*}}\right), j \in B$ and $c_{\mathrm{j}}^{*}=\max _{i} \quad$ if $j \in B$ (benefit criteria)

$\tilde{\mathrm{r}}_{\mathrm{ij}}=\left(\frac{\mathrm{c}_{\mathrm{j}}^{-}}{\mathrm{c}_{\mathrm{ij}}}, \frac{\mathrm{c}_{\mathrm{j}}^{-}}{\mathrm{b}_{\mathrm{ij}}}, \frac{\mathrm{c}_{\mathrm{j}}^{-}}{\mathrm{a}_{\mathrm{ij}}}\right), j \in C$ and $\mathrm{c}_{\mathrm{j}}^{-}=\min _{\mathrm{i}} \mathrm{a}_{\mathrm{ij}}$ if $j \in C$ (cost criteria)

$\widetilde{R}$ : Normalized fuzzy decision matrix

$\mathrm{c}_{\mathrm{j}}^{*}$ : Maximum value of the third component in one column in fuzzy decision matrix

$\tilde{r}_{i j}$ : Normalized values obtained by dividing each value in fuzzy decision matrix into $c_{j}^{*}$ value. Each of $a, b, c$ are the values in the fuzzy decision matrix.

Step 7. Structure the weighted normalized matrix.

$\widetilde{V}=\left[\tilde{v}_{i j}\right]_{m x n}, \quad i=1,2, \ldots, m ; j=1,2, \ldots, n$ where $\tilde{v}_{i j}=\tilde{r}_{i j}(.) \widetilde{w}_{j}$

Step 8. Compute the distance of each alternative from fuzzy positive-ideal solution (FPIS) and fuzzy negative-ideal solution (FNIS), respectively as follows:

$A^{*}=\left(\tilde{v}_{1}{ }^{*}, \tilde{v}_{2}{ }^{*}, \ldots, \tilde{v}_{n}{ }^{*}\right)$ where $\tilde{v}_{j}^{*}=\max _{i} v_{i j} \quad i=1,2, \ldots, m ; j=1,2, \ldots, n$

$A^{-}=\left(\tilde{v}_{1}{ }^{-}, \tilde{v}_{2}{ }^{-}, \ldots, \tilde{v}_{n}{ }^{-}\right)$where $\tilde{v}_{j}^{-}=\min _{i} v_{i j} i=1,2, \ldots, m ; j=1,2, \ldots, n$

Compute the distance of each alternative from FPIS and FNIS.

$$
d_{i}^{*}=\sum_{j=1}^{n} d\left(\tilde{v}_{i j}, \tilde{v}_{j}^{*}\right), \quad i=1,2, \ldots, m \quad \text { (11) } \quad d_{i}^{-}=\sum_{j=1}^{n} d\left(\tilde{v}_{i j}, \tilde{v}_{j}^{-}\right) i=1,2, \ldots, m
$$

Where; $d(.,$.$) refers to the distance between two triangular fuzzy numbers. This distance is found$ using vertex method and this method is used for finding the distance between " $m$ " and " $n$ " (Chen, 2000). $\widetilde{\mathrm{m}}=\left(\mathrm{m}_{1}, \mathrm{~m}_{2}, \mathrm{~m}_{3}\right)$ and $\widetilde{\mathrm{n}}=\left(\mathrm{n}_{1}, \mathrm{n}_{2}, \mathrm{n}_{3}\right)$ 
$\mathrm{d}(\widetilde{\mathrm{m}}, \tilde{\mathrm{n}})=\sqrt{\frac{1}{3}\left[\left(\mathrm{~m}_{1}-\mathrm{n}_{1}\right)^{2}+\left(\mathrm{m}_{2}-\mathrm{n}_{2}\right)^{2}+\left(\mathrm{m}_{3}-\mathrm{n}_{3}\right)^{2}\right]}$

Step 9. Calculate the closeness coefficient of each alternative. Then, rank the alternatives according to their closeness coefficients that are between 0 and 1 , and finally choose the alternative whose closeness coefficient is adjacent to 1 .

$$
\mathrm{CC}_{\mathrm{i}}=\frac{\mathrm{d}_{\mathrm{i}}^{-}}{\mathrm{d}_{\mathrm{i}}^{*}+\mathrm{d}_{\mathrm{i}}^{-}}, \mathrm{i}=1,2, \ldots, \mathrm{m}
$$

\subsection{Fuzzy ELECTRE I Method}

ELECTRE I (ELimination Et Choix Traduisant la REalitéwas developed by Benayoun et al. (1966). The method uses concordance and discordance indexes to analyze the outranking relations among different alternatives (Rouyendegh and Erkan, 2013). Although linguistic variables and the evaluation of weightings are the same in both multi criteria decision methods, there are several differences between fuzzy TOPSIS and fuzzy ELECTRE I. The main difference between them is the ranking mechanism. Fuzzy ELECTRE I focuses on the selection of a single action among a small set of available actions, while fuzzy TOPSIS aims to select a complete or partial order of the actions. The fuzzy ELECTRE I method proposed here can be described in 13 steps. The first seven steps in the Fuzzy ELECTRE method are the same as Fuzzy TOPSIS method. Hatami-Marbini and Tavana (2011) and Hatami-Marbini et al. (2013) describe the extensions towards fuzzy ELECTRE I.

Let us assume that decision making committee involves $K$ decision makers (DMs) $D_{k}(k=1$, $2, \ldots, K)$. The DMs are expected to determine the importance weights of $n$ criteria $C_{j}(j=1,2, \ldots$ ,n) and the performance ratings of $m$ possible alternatives $A_{i}(i=1,2, \ldots, m)$ on the attributes by means of linguistic variables.

Step 8: Compute the distance between any two options: The concordance and discordance matrices are structured by using the weighted normalized fuzzy decision matrix $(\tilde{v})$ and paired comparison among the alternatives Hatami-Marbini et al. (2013). In this study, Hamming distance (Hamming, 1950), denoted as $d(\tilde{a}, \tilde{b})$ between given two fuzzy numbers $\tilde{m}$ and $\tilde{n}$ is computed as follows:

$d(\tilde{a}, \tilde{b})=\int_{R}\left|\mu_{\tilde{\mathrm{a}}}(\mathrm{x})-\mu_{\widetilde{\mathrm{b}}}(\mathrm{x})\right| d x$ 
where $\mathrm{R}$ is the set of real numbers.

For each pair of alternatives $A_{p}$ and $A_{r}(\mathrm{p}, \mathrm{r}=1,2, \ldots, \mathrm{m}$ and $\mathrm{p} \neq \mathrm{r})$ the set of criteria is divided into two distinct subsets. Taking two alternatives $A_{p}$ and $A_{r}$, the concordance set is formed as $J^{x}=\left\{j \mid \tilde{v}_{p j} \geq \tilde{v}_{r j}\right\}$ where $J^{x}$ is the concordance coalition of the attributes where $A_{p} \mathrm{~S} A_{r}$, and the discordance set is defined by $J^{y}=\left\{j \mid \tilde{v}_{p j} \leq \tilde{v}_{r j}\right\}$ in which $J^{y}$ is the discordance coalition, which is against the assertion $A_{p} \mathrm{~S} A_{r}$. In order to compare any two alternatives $A_{p}$ and $A_{r}$ with respect to each attribute, and to define the concordance and discordance sets, the least upper bound of the alternatives are specified, $\max \left(\tilde{v}_{p j}, \tilde{v}_{r j}\right)$. After that the Hamming distance is applied based on the following formulation Hatami-Marbini et al. (2013):

$$
\begin{aligned}
& \tilde{v}_{p j} \geq \tilde{v}_{r j} \Leftrightarrow d\left(\max \left(\tilde{v}_{p j}, \tilde{v}_{r j}\right), \tilde{v}_{r j}\right) \geq d\left(\max \left(\tilde{v}_{p j}, \tilde{v}_{r j}\right), \tilde{v}_{p j}\right) \text { and } \\
& \tilde{v}_{p j} \leq \tilde{v}_{r j} \Leftrightarrow d\left(\max \left(\tilde{v}_{p j}, \tilde{v}_{r j}\right), \tilde{v}_{r j}\right) \leq d\left(\max \left(\tilde{v}_{p j}, \tilde{v}_{r j}\right), \tilde{v}_{p j}\right)
\end{aligned}
$$

Step 9: Compute the concordance matrix: The concordance matrix is constructed based on the Hamming distance. The elements of the concordance matrix are specified as fuzzy summation of the fuzzy weights of all criteria in the concordance set.

$$
\widetilde{\mathrm{X}}=\left[\begin{array}{cccc}
- & \tilde{x}_{1 r} & \ldots & \tilde{x}_{1 m} \\
\tilde{x}_{p 1} & \tilde{x}_{p r} & \cdots & \tilde{x}_{p m} \\
\vdots & \vdots & \ldots & \vdots \\
\tilde{x}_{m 1} & \tilde{x}_{m r} & \cdots & -
\end{array}\right]
$$

Where

$$
\tilde{x}_{p r}=\left(x_{p r}^{l}, x_{p r}^{m}, x_{p r}^{u}\right)=\sum_{j \in J^{x}} \widetilde{W}_{j}=\left(\sum_{j \in J^{x}} w_{j,}^{l} \sum_{j \in J^{x}} w_{j,}^{m} \sum_{j \in J^{x}} w_{j,}^{u}\right)
$$

We then specify the concordance level as $\tilde{\mathrm{x}}=\left(x^{L}, x^{M}, x^{U}\right)$, where

$$
x^{l}=\frac{\sum_{r=1}^{m} \sum_{p=1}^{m} x_{p r}^{l}}{m(n-1)}, x^{m}=\frac{\sum_{r=1}^{m} \sum_{p=1}^{m} x_{p r}^{m}}{m(m-1)} \text { and } x^{u}=\frac{\sum_{r=1}^{m} \sum_{p=1}^{m} x_{p r}^{u}}{m(m-1)}
$$

Step 10: Compute the discordance matrix: The discordance matrix is constructed with respect to the Hamming distance. The discordance matrix can be described as; 
$\widetilde{Y}=\left[\begin{array}{cccc}- & \tilde{y}_{1 r} & \cdots & \tilde{y}_{1 m} \\ \tilde{y}_{p 1} & \tilde{y}_{p r} & \cdots & \tilde{y}_{p m} \\ \vdots & \vdots & \cdots & \vdots \\ \tilde{y}_{m 1} & \tilde{y}_{m r} & \cdots & -\end{array}\right]$

Where

$$
y_{p r}=\frac{\max _{j \epsilon J^{y}}\left|\tilde{v}_{p j}-\tilde{v}_{r j}\right|}{\max _{j} \tilde{v}_{p j}-\tilde{v}_{r j} \mid}=\frac{\max _{j \epsilon J^{y}}\left|\mathrm{~d}\left(\max \left(\tilde{v}_{p j}, \tilde{v}_{r j}\right), \tilde{v}_{r j}\right)\right|}{\max _{j} \mathrm{~d}\left(\max \left(\tilde{v}_{p j}, \tilde{v}_{r j}\right), \tilde{v}_{r j}\right) \mid}
$$

and the discordance level is described as;

$$
\bar{Y}=\frac{\sum_{r=1}^{m} \sum_{p=1}^{m} y_{p r}}{m(m-1)}
$$

Step 11: Calculate the Boolean Matrices $G$ and H: Boolean matrix $G$ is formed according to the minimum concordance level $\tilde{\bar{X}}$ as

$$
G=\left[\begin{array}{cccc}
- & g_{1 r} & \ldots & g_{1 m} \\
g_{p 1} & g_{p r} & \ldots & g_{p m} \\
\vdots & \vdots & \ldots & \vdots \\
g_{m 1} & g_{m r} & \ldots & -
\end{array}\right] \quad \text { (22) } \quad\left\{\begin{array}{l}
\tilde{x}_{p r} \geq \tilde{\bar{X}} \Leftrightarrow g_{p r}=1 \\
\tilde{x}_{p r}<\tilde{\bar{X}} \Leftrightarrow g_{p r}=0
\end{array}\right.
$$

and similarly, the Boolean matrix $H$ is obtained based on the minimum discordance level, $\bar{Y}$ as follows:

$$
H=\left[\begin{array}{cccc}
- & h_{1 r} & \ldots & h_{1 m} \\
h_{p 1} & h_{p r} & \ldots & h_{p m} \\
\vdots & \vdots & \ldots & \vdots \\
h_{m 1} & h_{m r} & \ldots & -
\end{array}\right] \quad \text { (24) } \quad\left\{\begin{array}{l}
\tilde{y}_{p r}<\bar{Y} \Leftrightarrow h_{p r}=1 \\
\tilde{y}_{p r} \geq \bar{Y} \Leftrightarrow h_{p r}=0
\end{array}\right.
$$

The elements in matrices $\mathrm{G}$ and $\mathrm{H}$ with the value of "1" indicate the relation of dominance between alternatives.

Step 12: Calculate the global matrix: The global matrix $Z$ is calculated by multiplication of the elements of the matrices $G$ and $H$ as follows

$Z=G \otimes H$

where each element $\left(z_{p r}\right)$ of matrix $Z$ is obtained using $z_{p r}=g_{p r} \cdot h_{p r}$

Step 13: Draw a decision graph and rank the alternatives: With regard to the general matrix, a decision graph is drawn in order to determine the ranking order of the alternatives. There is an arc 
between the two alternatives from $A_{p}$ to $A_{r}$ in case that alternative $A_{p}$ outranks $A_{r}$, on the other hand there is no arc between the two alternatives if alternatives $A_{p}$ and $A_{r}$ are incomparable, and lastly there are two arcs between the two alternatives in both directions if these alternatives are indifferent Hatami-Marbini and Tavana (2011).

\subsection{Fuzzy VIKOR Method}

VIKOR method is one of the MCDM methods developed by Opricovic (1998) for the multicriteria optimization of complex systems. The purpose of the method is to reach a compromise solution which would provide maximum group benefit (majority rule) and minimum individual regret at the stage of listing and selection of the alternatives. The method is used for the cases where multi criteria have to be considered on the final decision in the process of selection among the alternatives (Opricovic and Tzeng, 2004). And Fuzzy VIKOR method, the form in which fuzzy logic is applied to the VIKOR method, is a method appropriate for use in cases where different criteria which are determinant of the final decision and conflicting with one another within an indefinite framework are in question. A compromise solution is obtained by the VIKOR method of compromise ranking, which in turn provides a maximum "group utility" for the "majority" and a minimum of an individual regret for the "opponent" (Opricovic, 2011). The steps used for the solution of multi-criteria decision problems using Fuzzy VIKOR method can be described as the following. The first five steps in the Fuzzy VIKOR method are the same as Fuzzy TOPSIS method as shown in the Fig. 1. To prevent unnecessary repetition of describing steps, only the steps after the $6^{\text {th }}$ step are shown.

Step 6: The best and worst values of all criteria functions are determined (alternatives $i=1,2, \ldots$, $\mathrm{m})$. The equation numbered (27) is used for calculating the best value and the equation numbered (28) is used for calculating the worst value (criteria $\mathrm{j}=1,2, \ldots, \mathrm{n} ; \mathrm{x}_{\mathrm{ij}}=$ Aggregated fuzzy ratings).

$$
\tilde{\mathrm{f}}_{\mathrm{i}}^{*}=\max _{\mathrm{j}} \mathrm{x}_{\mathrm{ij}} \quad \text { (27) } \quad \tilde{\mathrm{f}}_{\mathrm{i}}^{-}=\underset{\mathrm{j}}{\max x_{\mathrm{ij}}}
$$

Step 7: $\widetilde{S}_{\mathrm{j}}(29)$ and $\widetilde{\mathrm{R}}_{\mathrm{j}}(30)$ values are calculated for $\mathrm{j}=1,2, \ldots, \mathrm{n}$ and $\mathrm{i}=1,2, \ldots, \mathrm{m}$.

$$
\begin{aligned}
& \tilde{\mathrm{S}}_{j}=\sum_{\mathrm{j}=1}^{\mathrm{n}}\left[\widetilde{\mathrm{w}}_{\mathrm{i}}\left(\tilde{\mathrm{f}}_{\mathrm{i}}^{*}-\mathrm{x}_{\mathrm{ij}}\right) /\left(\tilde{\mathrm{f}}_{\mathrm{i}}^{*}-\tilde{\mathrm{f}}_{\mathrm{i}}^{-}\right)\right], \\
& \widetilde{\mathrm{R}}_{\mathrm{j}}=\underset{\mathrm{i}}{\max }\left[\widetilde{\mathrm{w}}_{\mathrm{i}}\left(\tilde{\mathrm{f}}_{\mathrm{i}}^{*}-\mathrm{x}_{\mathrm{ij}}\right) /\left(\tilde{\mathrm{f}}_{\mathrm{i}}^{*}-\tilde{\mathrm{f}}_{\mathrm{i}}^{-}\right)\right],
\end{aligned}
$$


While $\widetilde{\mathrm{w}}_{\mathrm{i}}$ refers to criteria weight and significance, $\widetilde{S}_{\mathrm{j}}$ is the distance of " $\mathrm{i}$ " alternative to the best fuzzy values and $\widetilde{\mathrm{R}}_{\mathrm{j}}$ value is the maximum distance of " $\mathrm{i}$ " alternative to the worst fuzzy values (Akyuz, 2012).

Step 8: $\widetilde{\mathrm{S}}_{\mathrm{i}}, \widetilde{\mathrm{S}}^{*}(31), \widetilde{\mathrm{R}}_{\mathrm{i}}, \widetilde{\mathrm{R}}^{*}(32)$ and $\widetilde{\mathrm{Q}}_{\mathrm{i}}(33)$ values that refer to maximum group benefit are calculated.

$\tilde{\mathrm{S}}^{*}=\min _{\mathrm{i}} \tilde{\mathrm{S}}_{\mathrm{i}} \quad$ and $\quad \tilde{\mathrm{S}}^{-}=\max _{\mathrm{i}} \tilde{\mathrm{S}}_{\mathrm{i}}$

$\widetilde{\mathrm{R}}^{*}=\min _{\mathrm{i}} \widetilde{\mathrm{R}}_{\mathrm{i}} \quad$ and $\quad \widetilde{\mathrm{R}}^{-}=\max _{\mathrm{i}} \widetilde{\mathrm{R}}_{\mathrm{i}}$

$\widetilde{\mathrm{Q}}_{\mathrm{i}}=\mathrm{v}\left(\widetilde{\mathrm{S}}_{\mathrm{i}}-\widetilde{\mathrm{S}}^{*}\right) /\left(\widetilde{\mathrm{S}}^{-}-\widetilde{\mathrm{S}}^{*}\right)+(1-\mathrm{v})\left(\widetilde{\mathrm{R}}_{\mathrm{i}}-\widetilde{\mathrm{R}}^{*}\right) /\left(\widetilde{\mathrm{R}}^{-}-\widetilde{\mathrm{R}}^{*}\right)$

$\widetilde{S}^{*}$ refers to compromising majority rule and $\widetilde{\mathrm{R}}^{*}$ refers to minimum individual regrets of those having different alternatives. Following those calculations $\widetilde{Q}_{i}$ index is obtained, this index is calculated through joint assessment of group benefit and individual regret. And while the "v" value underlines the significance of the strategy that provides majority of the criteria or maximum group benefit (v=0.5) "1-v" corresponds to individual regret value (Opricovic, 2011).

Step 9: Triangular fuzzy numbers are simplified and alternatives are listed according to " $\widetilde{Q}_{i}$ " index. The minimum value of this index indicates the best alternative. In this study, BNP (Best Nonfuzzy Performance Value) simplification method suggested by Hsieh et.al. (2004) (see Equation (34)) is used.

$$
\mathrm{BNP}_{\mathrm{i}}=\frac{\left(\mathrm{u}_{\mathrm{i}}-\mathrm{l}_{\mathrm{i}}\right)+\left(\mathrm{m}_{\mathrm{i}}-\mathrm{l}_{\mathrm{i}}\right)}{3}+\mathrm{l}_{\mathrm{i}} \quad \mathrm{i}=1,2, \ldots, \mathrm{m}
$$

Step 10: The two following conditions should be met to determine the compromising solution.

$I^{\text {st }}$ Condition: Acceptable advantage

$Q\left(a^{\prime \prime}\right)-Q\left(a^{\prime}\right) \geq D Q$ and $D Q=\frac{1}{m-1}($ if $m \leq 4$ then $D Q=0.25)$

$2^{\text {nd }}$ Condition: Stability acceptable in decision making 
Alternative $\mathrm{a}^{\prime}$ should be the best alternative in the ranking made according to $\mathrm{S}$ and/or $\mathrm{R}$ values (Opricovic and Tzeng, 2004). If the $1^{\text {st }}$ Condition cannot be provided, $Q\left(a^{(m)}\right)-Q\left(a^{\prime}\right) \leq D Q$ and if it is made $a^{(m)}$ and $a^{\prime}$ should be the same compromising solution.

If the $2^{\text {nd }}$ Condition cannot be provided although a' has a relative advantage there is inconsistency in decision making. For this reason a'and a" compromising solutions are the same.

Step 11: The minimum "Q" value among alternatives is selected.

\section{Case Study}

This study presents a model using the methods described above for selecting candidate sites for underground $\mathrm{CO}_{2}$ geological storage in Turkey. A committee of four decision makers $\mathrm{D}_{1}, \mathrm{D}_{2}$, $D_{3}$ and $D_{4}$ was formed to select the best alternative using 12 criteria as provided in Table 2. Five alternative locations for depleted reservoirs (depleted oil and gas reservoirs, aquifer reservoirs, salt cavern reservoirs, coal mine and mined cavern) are determined by four experts: Adiyaman, Aksaray, Diyarbakir, Afyon and Tekirdag. Hierarchical structure for a location selection problem is shown in Fig. 2.

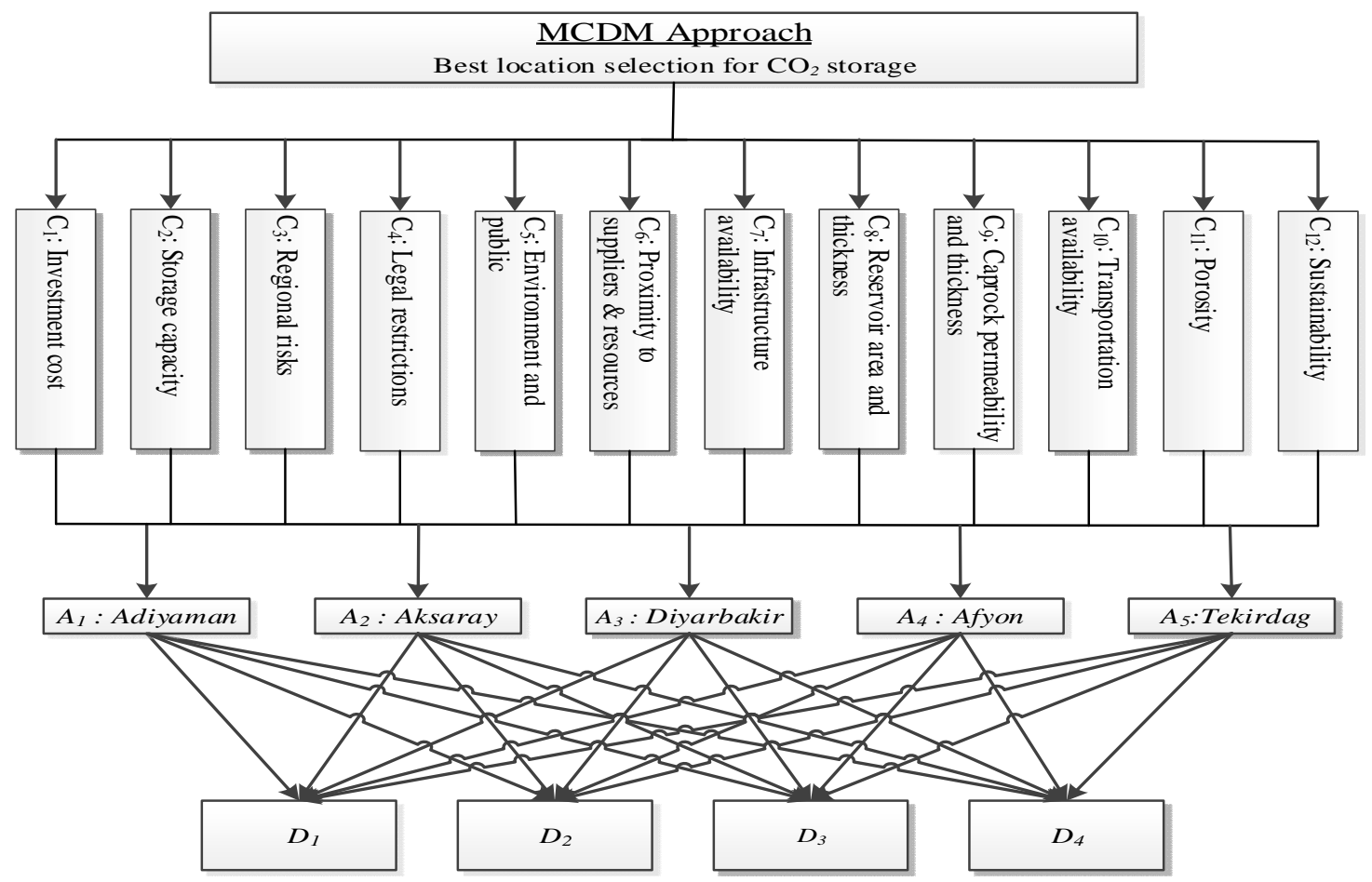

Fig. 2. The decision hierarchy of the location selection problem. 


\subsection{Fuzzy TOPSIS Solutions}

The linguistic assessments for the twelve criteria are determined by the committee using rating scales (see Table 3), which also evaluate the five alternatives (locations) for each of the 12 criteria (using rating scales of Table 3). Tables 4 and 5 present the linguistic assessments for the criteria and alternatives. The aggregate weights of the 12 criteria are presented in Table 6 .

Table 4

Linguistic assessments for the 12 criteria.

\begin{tabular}{|c|c|c|c|c|c|c|c|c|c|c|c|c|}
\hline \multirow{2}{*}{$\begin{array}{c}\text { Decision } \\
\text { makers }\end{array}$} & \multicolumn{12}{|c|}{ Criteria } \\
\hline & $\mathrm{C}_{1}$ & $\mathrm{C}_{2}$ & $\mathrm{C}_{3}$ & $\mathrm{C}_{4}$ & $\mathrm{C}_{5}$ & $\mathrm{C}_{6}$ & $\mathrm{C}_{7}$ & $\mathrm{C}_{8}$ & $\mathrm{C}_{9}$ & $\mathrm{C}_{10}$ & $\mathrm{C}_{11}$ & $\mathrm{C}_{12}$ \\
\hline D1 & $\mathrm{H}$ & $\mathrm{VH}$ & $\mathrm{H}$ & $\mathrm{MH}$ & $\mathrm{L}$ & $\mathrm{MH}$ & $\mathrm{H}$ & $\mathrm{H}$ & $\mathrm{H}$ & $\mathrm{VH}$ & $\mathrm{H}$ & $\mathrm{MH}$ \\
\hline D2 & MH & $\mathrm{M}$ & VH & $\mathrm{H}$ & $\mathrm{M}$ & $\mathrm{M}$ & VH & MH & $\mathrm{VH}$ & M & $\mathbf{M}$ & MH \\
\hline D3 & VH & MH & VH & $\mathrm{H}$ & M & VH & $\mathrm{H}$ & $\mathrm{VH}$ & $\mathrm{H}$ & $\mathrm{MH}$ & $\mathrm{M}$ & $\mathrm{H}$ \\
\hline D4 & $\mathrm{VH}$ & $\mathrm{VH}$ & VH & M & $\mathrm{MH}$ & $\mathrm{H}$ & VH & $\mathrm{MH}$ & $\mathrm{VH}$ & $\mathrm{H}$ & $\mathrm{MH}$ & M \\
\hline
\end{tabular}

Table 5

Linguistic assessments for the five alternatives.

\begin{tabular}{|c|c|c|c|c|c|c|c|c|c|c|c|c|c|}
\hline \multirow{2}{*}{ Alternatives } & \multirow{2}{*}{$\begin{array}{l}\text { Decision } \\
\text { makers }\end{array}$} & \multicolumn{12}{|c|}{ Criteria } \\
\hline & & $\mathrm{C}_{1}$ & $\mathrm{C}_{2}$ & $\mathrm{C}_{3}$ & $\mathrm{C}_{4}$ & $\mathrm{C}_{5}$ & $\mathrm{C}_{6}$ & $\mathrm{C}_{7}$ & $\mathrm{C}_{8}$ & $\mathrm{C}_{9}$ & $\mathrm{C}_{10}$ & $\mathrm{C}_{11}$ & $\mathrm{C}_{12}$ \\
\hline \multirow{4}{*}{$\mathrm{A}_{1}$} & $\mathrm{D}_{1}$ & VG & G & G & $\mathrm{F}$ & VG & G & G & G & G & $\mathrm{F}$ & G & $\mathrm{G}$ \\
\hline & $\mathrm{D}_{2}$ & $\mathrm{G}$ & G & G & MG & G & MG & G & $\mathrm{F}$ & G & $\mathrm{F}$ & $\mathrm{F}$ & $\mathrm{G}$ \\
\hline & $\mathrm{D}_{3}$ & MG & MG & VG & $\mathrm{F}$ & MG & $\mathrm{F}$ & $\mathrm{F}$ & MP & VG & MP & MP & $\mathrm{F}$ \\
\hline & $\mathrm{D}_{4}$ & VG & MG & MG & $\mathrm{F}$ & MG & VG & MG & $\mathrm{F}$ & $\mathrm{F}$ & MP & $\mathrm{F}$ & $\mathrm{F}$ \\
\hline \multirow{4}{*}{$\mathrm{A}_{2}$} & $\mathrm{D}_{1}$ & MG & MG & $\mathrm{F}$ & $\mathrm{F}$ & G & G & MG & $\mathrm{F}$ & $\mathrm{G}$ & $\mathrm{F}$ & MP & G \\
\hline & $\mathrm{D}_{2}$ & F & $\mathrm{F}$ & VP & VG & MG & MP & G & VG & MP & MP & MP & MG \\
\hline & $D_{3}$ & MP & MP & $\mathrm{F}$ & G & VG & $\mathrm{F}$ & G & G & $\mathrm{F}$ & $\mathrm{P}$ & $\mathrm{P}$ & $\mathrm{F}$ \\
\hline & $\mathrm{D}_{4}$ & $\mathrm{~F}$ & MP & VP & G & MG & MP & $\mathrm{F}$ & VG & $\mathrm{F}$ & $\mathrm{F}$ & $\mathrm{F}$ & G \\
\hline \multirow{4}{*}{$\mathrm{A}_{3}$} & $\mathrm{D}_{1}$ & VG & VG & $\mathrm{MG}$ & $\mathrm{G}$ & $\mathrm{G}$ & VG & VG & $\mathrm{G}$ & F & VG & MG & VG \\
\hline & $\mathrm{D}_{2}$ & VG & $\mathrm{G}$ & $\mathrm{G}$ & $\mathrm{F}$ & $\mathrm{G}$ & MG & $\mathrm{G}$ & $\mathrm{MG}$ & $\mathrm{G}$ & VG & G & $\mathrm{G}$ \\
\hline & $\mathrm{D}_{3}$ & G & G & VG & G & VG & G & G & MG & G & G & G & VG \\
\hline & $\mathrm{D}_{4}$ & G & MG & VG & VG & VG & G & VG & G & MG & G & MG & VG \\
\hline \multirow{4}{*}{$\mathrm{A}_{4}$} & $\mathrm{D}_{1}$ & MP & $\mathrm{P}$ & VP & G & MG & VP & MG & MP & G & MP & G & VG \\
\hline & $\mathrm{D}_{2}$ & $\mathrm{~F}$ & VP & MP & G & $\mathrm{F}$ & MP & G & $\mathrm{P}$ & VG & $\mathrm{F}$ & VG & $\mathrm{G}$ \\
\hline & $\mathrm{D}_{3}$ & $\mathrm{~F}$ & VP & VP & VG & $\mathrm{F}$ & $\mathrm{F}$ & G & VP & $\mathrm{F}$ & $\mathrm{F}$ & MG & $\mathrm{F}$ \\
\hline & $\mathrm{D}_{4}$ & MG & $\mathrm{F}$ & MP & G & G & $\mathrm{F}$ & G & $\mathrm{P}$ & MG & MP & $\mathrm{F}$ & $\mathrm{G}$ \\
\hline \multirow{3}{*}{$\mathrm{A}_{5}$} & $\mathrm{D}_{1}$ & $\mathrm{G}$ & $\mathrm{F}$ & $\mathrm{F}$ & VG & $\mathrm{G}$ & $\mathrm{G}$ & $\mathrm{G}$ & $\mathrm{F}$ & $\mathrm{G}$ & $\mathrm{G}$ & G & $\mathrm{G}$ \\
\hline & $\mathrm{D}_{2}$ & G & $\mathrm{F}$ & MP & VG & VG & MG & VG & MG & G & MG & G & MG \\
\hline & $\mathrm{D}_{3}$ & $\mathrm{MG}$ & MP & $\mathrm{F}$ & $\mathrm{G}$ & $\mathrm{MG}$ & F & MG & F & MG & F & F & $\mathrm{G}$ \\
\hline
\end{tabular}




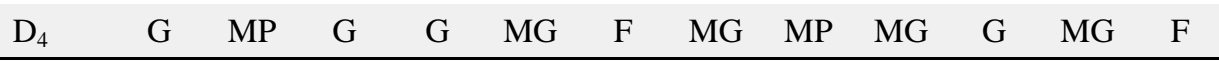

The fuzzy weights $\left(\widetilde{\mathrm{w}}_{\mathbf{j}}\right)$ for each criterion are computed by using Eq. (1). The aggregate fuzzy decision matrix for the alternatives is presented in Table 7.

Table 6

Aggregate fuzzy weights for criteria.

\begin{tabular}{|c|c|c|c|c|c|}
\hline \multirow{2}{*}{ Criteria } & \multicolumn{4}{|c|}{ Alternatives } & \multirow{2}{*}{$\begin{array}{c}\text { Fuzzy } \\
\text { Weights }\left(\widetilde{\mathrm{w}}_{\mathrm{j}}\right)\end{array}$} \\
\hline & D1 & D2 & D3 & D4 & \\
\hline $\mathrm{C}_{1}$ & $(0.70,0.90,1.00)$ & $(0.50,0.70,0.90)$ & $(0.90,1.00,1.00)$ & $(0.90,1.00,1.00)$ & $(0.75,0.90,0.98)$ \\
\hline $\mathrm{C}_{2}$ & $(0.90,1.00,1.00)$ & $(0.30,0.50,0.70)$ & $(0.50,0.70,0.90)$ & $(0.90,1.00,1.00)$ & $(0.65,0.80,0.90)$ \\
\hline $\mathrm{C}_{3}$ & $(0.70,0.90,1.00)$ & $(0.90,1.00,1.00)$ & $(0.90,1.00,1.00)$ & $(0.90,1.00,1.00)$ & $(0.85,0.98,1.00)$ \\
\hline $\mathrm{C}_{4}$ & $(0.50,0.70,0.90)$ & $(0.70,0.90,1.00)$ & $(0.70,0.90,1.00)$ & $(0.30,0.50,0.70)$ & $(0.55,0.75,0.90)$ \\
\hline $\mathrm{C}_{5}$ & $(0.10,0.30,0.50)$ & $(0.30,0.50,0.70)$ & $(0.30,0.50,0.70)$ & $(0.50,0.70,0.90)$ & $(0.30,0.50,0.70)$ \\
\hline $\mathrm{C}_{6}$ & $(0.50,0.70,0.90)$ & $(0.30,0.50,0.70)$ & $(0.90,1.00,1.00)$ & $(0.70,0.90,1.00)$ & $(0.60,0.78,0.90)$ \\
\hline $\mathrm{C}_{7}$ & $(0.70,0.90,1.00)$ & $(0.90,1.00,1.00)$ & $(0.70,0.90,1.00)$ & $(0.90,1.00,1.00)$ & $(0.80,0.95,1.00)$ \\
\hline $\mathrm{C}_{8}$ & $(0.70,0.90,1.00)$ & $(0.50,0.70,0.90)$ & $(0.90,1.00,1.00)$ & $(0.50,0.70,0.90)$ & $(0.65,0.83,0.95)$ \\
\hline $\mathrm{C}_{9}$ & $(0.70,0.90,1.00)$ & $(0.90,1.00,1.00)$ & $(0.70,0.90,1.00)$ & $(0.90,1.00,1.00)$ & $(0.80,0.95,1.00)$ \\
\hline $\mathrm{C}_{10}$ & $(0.90,1.00,1.00)$ & $(0.30,0.50,0.70)$ & $(0.50,0.70,0.90)$ & $(0.70,0.90,1.00)$ & $(0.60,0.78,0.90)$ \\
\hline $\mathrm{C}_{11}$ & $(0.70,0.90,1.00)$ & $(0.30,0.50,0.70)$ & $(0.30,0.50,0.70)$ & $(0.50,0.70,0.90)$ & $(0.45,0.65,0.83)$ \\
\hline $\mathrm{C}_{12}$ & $(0.50,0.70,0.90)$ & $(0.50,0.70,0.90)$ & $(0.70,0.90,1.00)$ & $(0.30,0.50,0.70)$ & $(0.50,0.70,0.88)$ \\
\hline
\end{tabular}

Table 7

The fuzzy decision matrix.

\begin{tabular}{cccccc}
\hline \multirow{2}{*}{ Criteria } & \multicolumn{5}{c}{ Alternatives } \\
\cline { 2 - 6 } & $\mathrm{A} 1$ & $\mathrm{~A} 2$ & $\mathrm{~A} 3$ & $\mathrm{~A} 4$ & $\mathrm{~A} 5$ \\
\hline $\mathrm{C}_{1}$ & $(7.50,9.00,9.75)$ & $(3.00,5.00,7.00)$ & $(8.00,9.50,10.0)$ & $(3.00,5.00,7.00)$ & $(6.50,8.50,9.75)$ \\
$\mathrm{C}_{2}$ & $(6.00,8.00,9.50)$ & $(2.50,4.50,6.50)$ & $(7.00,8.75,9.85)$ & $(0.75,1.50,3.00)$ & $(2.00,4.00,6.00)$ \\
$\mathrm{C}_{3}$ & $(7.00,8.75,9.75)$ & $(1.50,2.50,4.00)$ & $(7.50,9.00,9.75)$ & $(0.25,1.00,2.50)$ & $(3.50,5.50,7.25)$ \\
$\mathrm{C}_{4}$ & $(3.50,5.50,7.50)$ & $(6.50,8.25,9.25)$ & $(6.50,8.25,9.25)$ & $(7.50,9.25,10.0)$ & $(8.00,9.50,10.0)$ \\
$\mathrm{C}_{5}$ & $(6.50,8.25,9.50)$ & $(6.50,8.25,9.50)$ & $(8.00,9.50,10.0)$ & $(4.50,6.50,8.25)$ & $(6.50,8.25,9.50)$ \\
$\mathrm{C}_{6}$ & $(6.00,7.75,9.00)$ & $(3.00,5.00,6.75)$ & $(7.00,8.75,9.75)$ & $(1.75,3.25,5.00)$ & $(4.50,6.50,8.25)$ \\
$\mathrm{C}_{7}$ & $(5.50,7.50,9.00)$ & $(5.50,7.50,9.00)$ & $(8.00,9.50,10.0)$ & $(6.50,8.50,9.75)$ & $(6.50,8.25,9.50)$ \\
$\mathrm{C}_{8}$ & $(3.50,5.50,7.25)$ & $(7.00,8.50,9.25)$ & $(6.00,8.00,9.50)$ & $(0.25,1.25,3.00)$ & $(3.00,5.00,7.00)$ \\
$\mathrm{C}_{9}$ & $(6.50,8.25,9.25)$ & $(3.50,5.50,7.25)$ & $(5.50,7.50,9.00)$ & $(6.00,7.75,9.00)$ & $(6.00,8.00,9.50)$ \\
$\mathrm{C}_{10}$ & $(2.00,4.00,6.00)$ & $(1.75,3.50,5.50)$ & $(8.00,9.50,10.0)$ & $(2.00,4.00,6.00)$ & $(5.50,7.50,9.00)$ \\
$\mathrm{C}_{11}$ & $(3.50,5.50,7.25)$ & $(1.25,3.00,5.00)$ & $(6.00,8.00,9.50)$ & $(6.00,7.75,9.00)$ & $(5.50,7.50,9.00)$ \\
$\mathrm{C}_{12}$ & $(5.00,7.00,8.50)$ & $(5.50,7.50,9.00)$ & $(8.50,9.75,10.0)$ & $(6.50,8.25,9.25)$ & $(5.50,7.50,9.00)$ \\
\hline
\end{tabular}


Table 8

The fuzzy normalized decision matrix.

\begin{tabular}{cccccc}
\hline \multirow{2}{*}{ Criteria } & \multicolumn{5}{c}{ Alternatives } \\
\cline { 2 - 6 } & $\mathrm{A} 1$ & $\mathrm{~A} 2$ & $\mathrm{~A} 3$ & $\mathrm{~A} 4$ & $\mathrm{~A} 5$ \\
\hline $\mathrm{C}_{1}$ & $(0.31,0.33,0.40)$ & $(0.43,0.60,1.00)$ & $(0.30,0.32,0.38)$ & $(0.43,0.60,1.00)$ & $(0.31,0.35,0.46)$ \\
$\mathrm{C}_{2}$ & $(0.62,0.82,0.97)$ & $(0.26,0.46,0.67)$ & $(0.72,0.90,1.00)$ & $(0.08,0.15,0.31)$ & $(0.21,0.41,0.62)$ \\
$\mathrm{C}_{3}$ & $(0.03,0.03,0.04)$ & $(0.06,0.10,0.17)$ & $(0.03,0.03,0.03)$ & $(0.10,0.25,1.00)$ & $(0.03,0.05,0.07)$ \\
$\mathrm{C}_{4}$ & $(0.35,0.55,0.75)$ & $(0.65,0.83,0.93)$ & $(0.65,0.83,0.93)$ & $(0.75,0.93,1.00)$ & $(0.80,0.95,1.00)$ \\
$\mathrm{C}_{5}$ & $(0.65,0.83,0.95)$ & $(0.65,0.83,0.95)$ & $(0.80,0.95,1.00)$ & $(0.45,0.65,0.83)$ & $(0.65,0.83,0.95)$ \\
$\mathrm{C}_{6}$ & $(0.62,0.79,0.92)$ & $(0.31,0.51,0.69)$ & $(0.72,0.90,1.00)$ & $(0.18,0.33,0.51)$ & $(0.46,0.67,0.85)$ \\
$\mathrm{C}_{7}$ & $(0.55,0.75,0.90)$ & $(0.55,0.75,0.90)$ & $(0.80,0.95,1.00)$ & $(0.65,0.85,0.98)$ & $(0.65,0.83,0.95)$ \\
$\mathrm{C}_{8}$ & $(0.37,0.58,0.76)$ & $(0.74,0.89,0.97)$ & $(0.63,0.84,1.00)$ & $(0.03,0.13,0.32)$ & $(0.32,0.53,0.74)$ \\
$\mathrm{C}_{9}$ & $(0.68,0.87,0.97)$ & $(0.37,0.58,0.76)$ & $(0.58,0.79,0.95)$ & $(0.63,0.82,0.95)$ & $(0.63,0.84,1.00)$ \\
$\mathrm{C}_{10}$ & $(0.20,0.40,0.60)$ & $(0.18,0.35,0.55)$ & $(0.80,0.95,1.00)$ & $(0.20,0.40,0.60)$ & $(0.55,0.75,0.90)$ \\
$\mathrm{C}_{11}$ & $(0.37,0.58,0.76)$ & $(0.13,0.32,0.53)$ & $(0.63,0.84,1.00)$ & $(0.63,0.82,0.95)$ & $(0.58,0.79,0.95)$ \\
$\mathrm{C}_{12}$ & $(0.50,0.70,0.85)$ & $(0.55,0.75,0.90)$ & $(0.85,0.98,1.00)$ & $(0.65,0.83,0.93)$ & $(0.55,0.75,0.90)$ \\
\hline
\end{tabular}

Table 9

The fuzzy weighted normalized decision matrix.

\begin{tabular}{|c|c|c|c|c|c|c|c|}
\hline \multirow{2}{*}{ Criteria } & \multicolumn{5}{|c|}{ Alternatives } & \multirow{2}{*}{ FPIS (A*) } & \multirow{2}{*}{$\begin{array}{c}\text { FPNS } \\
\text { (A-) }\end{array}$} \\
\hline & A1 & $\mathrm{A} 2$ & A3 & A4 & A5 & & \\
\hline $\mathrm{C}_{1}$ & $(0.23,0.30,0.39)$ & $(0.32,0.54,0.98)$ & $(0.23,0.28,0.37)$ & $(0.32,0.54,0.98)$ & $(0.23,0.32,0.45)$ & $(1,1,1)$ & $(0,0,0)$ \\
\hline $\mathrm{C}_{2}$ & $(0.40,0.66,0.88)$ & $(0.17,0.37,0.60)$ & $(0.47,0.72,0.90)$ & $(0.05,0.12,0.28)$ & $(0.13,0.33,0.55)$ & $(1,1,1)$ & $(0,0,0)$ \\
\hline $\mathrm{C}_{3}$ & $(0.02,0.03,0.04)$ & $(0.05,0.10,0.17)$ & $(0.02,0.03,0.03)$ & $(0.09,0.24,1.00)$ & $(0.03,0.04,0.07)$ & $(1,1$ & $(0,0,0)$ \\
\hline $\mathrm{C}_{4}$ & $(0.19,0.41,0.68)$ & $(0.36,0.62,0.83)$ & $(0.36,0.62,0.83)$ & $(0.41,0.69,0.90)$ & $(0.44,0.71,0.90)$ & $(1,1,1)$ & $(0,0,0)$ \\
\hline $\mathrm{C}_{5}$ & $(0.20,0.41,0.67)$ & $(0.20,0.41,0.67)$ & $(0.24,0.48,0.70)$ & $(0.14,0.33,0.58)$ & $(0.20,0.41,0.67)$ & $(1,1,1)$ & $(0,0,0)$ \\
\hline $\mathrm{C}_{6}$ & $(0.37,0.62,0.83)$ & $(0.18,0.40,0.62)$ & $(0.43,0.70,0.90)$ & $(0.11,0.26,0.46)$ & $(0.28,0.52,0.76)$ & $(1,1,1)$ & $(0,0,0)$ \\
\hline $\mathrm{C}_{7}$ & $(0.44,0.71,0.90)$ & $(0.44,0.71,0.90)$ & $(0.64,0.90,1.00)$ & $(0.52,0.81,0.98)$ & $(0.52,0.78,0.95)$ & $(1,1,1)$ & $(0,0,0)$ \\
\hline $\mathrm{C}_{8}$ & $(0.24,0.48,0.73)$ & $(0.48,0.74,0.93)$ & $(0.41,0.69,0.95)$ & $(0.02,0.11,0.30)$ & $(0.21,0.43,0.70)$ & $(1,1,1)$ & $(0,0,0)$ \\
\hline $\mathrm{C}_{9}$ & $(0.55,0.83,0.97)$ & $(0.29,0.55,0.76)$ & $(0.46,0.75,0.95)$ & $(0.51,0.78,0.95)$ & $(0.51,0.80,1.00)$ & $(1,1,1)$ & $(0,0,0)$ \\
\hline $\mathrm{C}_{10}$ & $(0.12,0.31,0.54)$ & $(0.11,0.27,0.50)$ & $(0.48,0.74,0.90)$ & $(0.12,0.31,0.54)$ & $(0.33,0.58,0.81)$ & $(1,1,1)$ & $(0,0,0)$ \\
\hline $\mathrm{C}_{11}$ & $(0.17,0.38,0.63)$ & $(0.06,0.21,0.43)$ & $(0.28,0.55,0.83)$ & $(0.28,0.53,0.78)$ & $(0.26,0.51,0.78)$ & $(1,1,1)$ & $(0,0,0)$ \\
\hline $\mathrm{C}_{12}$ & $(0.25,0.49,0.74)$ & $(0.28,0.53,0.79)$ & $(0.43,0.68,0.88)$ & $(0.33,0.58,0.81)$ & $(0.28,0.53,0.79)$ & $(1,1,1)$ & $(0,0,0)$ \\
\hline
\end{tabular}

The fuzzy normalized decision matrices, constructed using Eq. (8) for the five alternatives are shown in Table 8 . The $\tilde{r}_{i j}$ values from Table 5 and $\widetilde{\mathrm{w}}_{\mathbf{j}}$ values from Table 4 are utilized to calculate the fuzzy weighted decision matrix for the alternatives. For alternative $A_{1}$, the fuzzy weight of 
criterion $\mathrm{C}_{2}$ (Storage capacity) is given by $\tilde{\mathrm{v}}_{\mathrm{ij}}=\widetilde{\mathrm{r}}_{\mathrm{ij}}(.) \widetilde{\mathrm{w}}_{\mathrm{j}}=(0.62,0.82,0.97)().(0.65,0.80,0.90)$ $\cong(0.40,0.66,0.88)$. Similarly, the fuzzy weights of five alternatives for the remaining criteria are calculated as summarised in Table 9.

\section{Table 10}

Distances $d\left(\mathrm{Aj}, \mathrm{A}^{*}\right)$ and $\mathrm{d}(\mathrm{Aj}, \mathrm{A}-)$ of the alternatives from fuzzy positive ideal solution (FPIS) and fuzzy negative ideal solution (FNIS) (i,j=1,2,3,4,5).

\begin{tabular}{|c|c|c|c|c|c|c|c|c|c|c|c|c|c|c|}
\hline \multirow{2}{*}{ Alternatives } & \multirow{2}{*}{$\begin{array}{c}\text { FPIS \& } \\
\text { FNIS } \\
\end{array}$} & \multicolumn{12}{|c|}{ Criteria } & \multirow{2}{*}{ Total } \\
\hline & & $\mathrm{C}_{1}$ & $\mathrm{C}_{2}$ & $\mathrm{C}_{3}$ & $\mathrm{C}_{4}$ & $\mathrm{C}_{5}$ & $\mathrm{C}_{6}$ & $\mathrm{C}_{7}$ & $\mathrm{C}_{8}$ & $\mathrm{C}_{9}$ & $\mathrm{C}_{10}$ & $\mathrm{C}_{11}$ & $\mathrm{C}_{12}$ & \\
\hline \multirow{2}{*}{$\mathrm{A}_{1}$} & $d\left(A_{1} \cdot A^{*}\right)$ & 0.70 & 0.41 & 0.97 & 0.61 & 0.61 & 0.44 & 0.37 & 0.56 & 0.28 & 0.70 & 0.64 & 0.54 & 6.809 \\
\hline & $d\left(A_{1} \cdot A^{-}\right)$ & 0.31 & 0.67 & 0.03 & 0.47 & 0.47 & 0.63 & 0.71 & 0.52 & 0.80 & 0.37 & 0.43 & 0.53 & 5.952 \\
\hline \multirow{2}{*}{$\mathrm{A}_{2}$} & $d\left(A_{2} \cdot A^{*}\right)$ & 0.47 & 0.65 & 0.90 & 0.44 & 0.61 & 0.62 & 0.37 & 0.34 & 0.50 & 0.73 & 0.78 & 0.52 & 6.923 \\
\hline & $d\left(A_{2} \cdot A^{-}\right)$ & 0.67 & 0.42 & 0.12 & 0.63 & 0.47 & 0.44 & 0.71 & 0.74 & 0.57 & 0.33 & 0.28 & 0.57 & 5.938 \\
\hline \multirow{2}{*}{$\mathrm{A}_{3}$} & $d\left(A_{3} \cdot A^{*}\right)$ & 0.71 & 0.35 & 0.97 & 0.44 & 0.56 & 0.38 & 0.22 & 0.38 & 0.34 & 0.34 & 0.50 & 0.39 & 5.586 \\
\hline & $d\left(A_{3} \cdot A^{-}\right)$ & 0.30 & 0.72 & 0.03 & 0.63 & 0.51 & 0.70 & 0.86 & 0.72 & 0.75 & 0.73 & 0.59 & 0.69 & 7.220 \\
\hline \multirow{2}{*}{$\mathrm{A}_{4}$} & $d\left(A_{4} \cdot A^{*}\right)$ & 0.47 & 0.86 & 0.69 & 0.39 & 0.68 & 0.74 & 0.30 & 0.87 & 0.32 & 0.70 & 0.51 & 0.47 & 6.980 \\
\hline & $d\left(A_{4} \cdot A^{-}\right)$ & 0.67 & 0.18 & 0.60 & 0.70 & 0.39 & 0.31 & 0.79 & 0.18 & 0.76 & 0.37 & 0.57 & 0.60 & 6.122 \\
\hline \multirow{2}{*}{$\mathrm{A}_{5}$} & $d\left(A_{5} \cdot A^{*}\right)$ & 0.67 & 0.68 & 0.95 & 0.37 & 0.61 & 0.52 & 0.31 & 0.59 & 0.31 & 0.47 & 0.53 & 0.52 & 6.518 \\
\hline & $d\left(A_{5} . A^{-}\right)$ & 0.34 & 0.38 & 0.05 & 0.71 & 0.47 & 0.55 & 0.77 & 0.49 & 0.79 & 0.61 & 0.56 & 0.57 & 6.299 \\
\hline
\end{tabular}

Once the fuzzy decision matrix is constructed, the next step is to compute the fuzzy normalized decision matrix as depicted in Table 9. The fuzzy weighted normalized decision matrix for the five alternatives is calculated using Eq. (8). Afterwards, using Eqs. (9) and (10), the fuzzy positive ideal solution (FPIS, $\mathrm{A}^{*}$ ) and negative ideal solution (FNIS, $\mathrm{A}^{-}$) are detected, as provided in Table 10. Then, the Euclidean distance of each alternative from $\mathrm{A}^{*}$ and $\mathrm{A}^{-}$can be computed using Eqs. (11), (12) and (13). Subsequently, the similarities to an ideal solution are found using Eq. (14). The values for each alternative for final ranking are shown in Table 11. Using the distances $d_{1}^{*}$ and $d_{1}^{-}$, we calculate the closeness coefficients $\left(\mathrm{CC}_{\mathrm{i}}\right)$ for all five alternatives using Eq. (14). For example, $\mathrm{CC}_{1}$ for the alternative $\mathrm{A}_{1}$ is as follows:

$$
\mathrm{CC}_{1}=\frac{\mathrm{d}_{1}^{-}}{\mathrm{d}_{1}^{*}+\mathrm{d}_{1}^{-}}=\frac{5.952}{5.952+6.809} \cong 0.466
$$


Table 11

Closeness coefficients $\left(\mathrm{CC}_{\mathrm{i}}\right)$ of the five alternatives.

\begin{tabular}{ccccc}
\hline Alternatives & $\mathrm{d}_{\mathrm{i}}^{*}$ & $\mathrm{~d}_{\mathrm{i}}^{-}$ & $\mathrm{CC}_{\mathrm{i}}$ & Ranking \\
\hline $\mathrm{A}_{1}$ & 6.809 & 5.952 & 0.466 & 4 \\
$\mathrm{~A}_{2}$ & 6.923 & 5.938 & 0.462 & 5 \\
$\mathrm{~A}_{3}$ & 5.586 & 7.220 & 0.564 & 1 \\
$\mathrm{~A}_{4}$ & 6.980 & 6.122 & 0.467 & 3 \\
$\mathrm{~A}_{5}$ & 6.518 & 6.299 & 0.491 & 2 \\
\hline
\end{tabular}

The closeness coefficient for each location considered for $\mathrm{CO}_{2}$ storage is shown in Table 11, yielding a final ranking of $A_{3}>A_{5}>A_{4}>A_{1}>A_{2} . A_{3}$ is the best among the five alternatives because it has the largest closeness coefficient $\left(\mathrm{CC}_{\mathrm{i}}\right)$, while $\mathrm{A}_{2}$ is the worst alternative.

\subsubsection{Sensitivity Analysis}

In here, we examine the impact of criteria weights on the location selection for $\mathrm{CO}_{2}$ storage using Fuzzy TOPSIS through sensitivity analysis (Awasthi et al., 2011). We have performed 17 experiments with different weight settings for the criteria (using rating scales of Table 3 ). In the first seven experiments, the weights of all criteria are set to $(0.9,1,1),(0.7,0.9,1),(0.5,0.7,0.9)$, $(0.3,0.5,0.7),(0.1,0.3,0.5),(0,0.1,0.3)$ and $(0,0,0.1)$. Then in the following experiments from $8-$ 13 , the weight of one criterion is set to the lowest (or highest) value, while the remaining weights are set to the highest (or lowest) value. For example, in experiment 11 , the criterion $\mathrm{C}_{1}$ has the highest weight $(0.7,0.9,1)$ while the remaining criteria have weight $(0.5,0.7,0.9)$.

The results from the sensitivity analysis are provided in Table 12 along with the settings used during each experiment and illustrated in Fig. 3. The location $A_{3}$ still turns out to be consistently the best alternative in all 17 experiments. This observation confirms that the location decision is relatively insensitive to the criteria weights while using Fuzzy TOPSIS.

Table 12

Experiments for sensitivity analysis.

\begin{tabular}{ccccccc}
\hline \multirow{5}{*}{$\begin{array}{c}\text { Experiment } \\
\text { Number }\end{array}$} & \multicolumn{5}{c}{$\mathrm{CC}_{\mathrm{i}}$} \\
\cline { 2 - 5 } & $\mathrm{A}_{1}$ & $\mathrm{~A}_{2}$ & $\mathrm{~A}_{3}$ & $\mathrm{~A}_{4}$ & $\mathrm{~A}_{5}$ & \\
\hline 1 & 0.567 & 0.556 & 0.700 & 0.556 & 0.602 & All criteria weights $=(0.9,1,1)$ \\
2 & 0.520 & 0.513 & 0.632 & 0.515 & 0.551 & All criteria weights $=(0.7,0.9,1)$ \\
3 & 0.440 & 0.436 & 0.530 & 0.441 & 0.466 & All criteria weights $=(0.5,0.7,0.9)$ \\
4 & 0.335 & 0.333 & 0.401 & 0.339 & 0.354 & All criteria weights $=(0.3,0.5,0.7)$ \\
5 & 0.227 & 0.228 & 0.268 & 0.233 & 0.240 & All criteria weights $=(0.1,0.3,0.5)$ \\
6 & 0.127 & 0.129 & 0.147 & 0.133 & 0.134 & All criteria weights $=(0,0.1,0.3)$ \\
7 & 0.042 & 0.043 & 0.048 & 0.044 & 0.044 & All criteria weights $=(0,0,0.1)$
\end{tabular}




\begin{tabular}{|c|c|c|c|c|c|c|}
\hline 8 & 0.523 & 0.516 & 0.635 & 0.519 & 0.553 & $\begin{array}{l}\text { Weight of criteria } 1=(0.9,1,1) \\
\text { Weight of remaining criteria }=(0.7,0.9,1)\end{array}$ \\
\hline 9 & 0.526 & 0.515 & 0.639 & 0.516 & 0.553 & $\begin{array}{l}\text { Weight of criteria } 2=(0.9,1,1) \\
\text { Weight of remaining criteria }=(0.7,0.9,1)\end{array}$ \\
\hline 10 & 0.563 & 0.555 & 0.694 & 0.551 & 0.597 & $\begin{array}{l}\text { Weight of criteria } 11=(0.7,0.9,1) \\
\text { Weight of remaining criteria }=(0.9,1,1)\end{array}$ \\
\hline 11 & 0.449 & 0.442 & 0.540 & 0.444 & 0.473 & $\begin{array}{l}\text { Weight of criteria } 6=(0.7,0.9,1) \\
\text { Weight of remaining criteria }=(0.5,0.7,0.9)\end{array}$ \\
\hline 12 & 0.347 & 0.345 & 0.414 & 0.349 & 0.366 & $\begin{array}{l}\text { Weight of criteria } 5=(0.5,0.7,0.9) \\
\text { Weight of remaining criteria }=(0.3,0.5,0.7)\end{array}$ \\
\hline 13 & 0.149 & 0.150 & 0.173 & 0.156 & 0.157 & $\begin{array}{l}\text { Weight of criteria } 7=(0.3,0.5,0.7) \\
\text { Weight of remaining criteria }=(0,0.1,0.3)\end{array}$ \\
\hline 14 & 0.453 & 0.451 & 0.545 & 0.457 & 0.479 & $\begin{array}{l}\text { Weight of criteria } 1 \& 8=(0.7,0.9,1) \\
\text { Weight of remaining criteria }=(0.5,0.7,0.9)\end{array}$ \\
\hline 15 & 0.270 & 0.256 & 0.315 & 0.281 & 0.287 & $\begin{array}{l}\text { Weight of criteria } 9 \& 11=(0.5,0.7,0.9) \\
\text { Weight of remaining criteria }=(0.1,0.3,0.5)\end{array}$ \\
\hline 16 & 0.467 & 0.459 & 0.565 & 0.465 & 0.491 & $\begin{array}{l}\text { Weight of criteria } 3.6 \& 12=(0.9,1,1) \\
\text { Weight of remaining criteria }=(0.5,0.7,0.9)\end{array}$ \\
\hline 17 & 0.502 & 0.495 & 0.629 & 0.511 & 0.550 & $\begin{array}{l}\text { Weight of criteria } 1.2 \& 5=(0.3,0.5,0.7) \\
\text { Weight of remaining criteria }=(0.9,1,1)\end{array}$ \\
\hline
\end{tabular}

Sensitivity Analysis

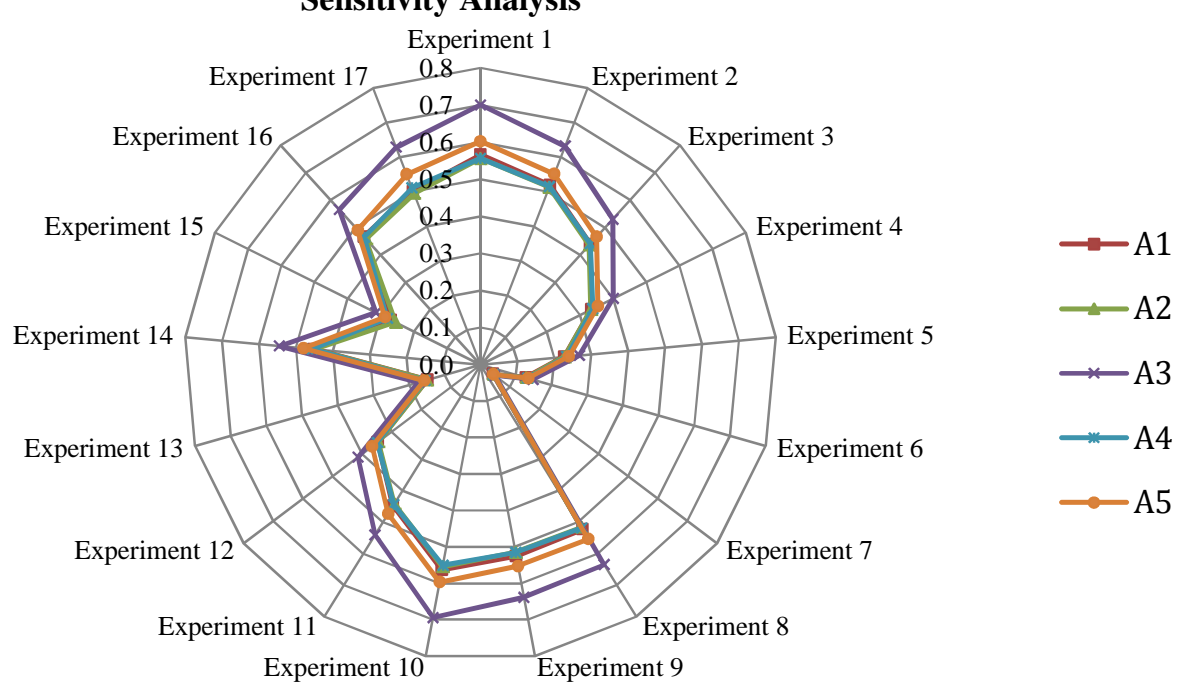

Fig. 3. Results of sensitivity analysis. 


\subsection{Fuzzy ELECTRE I Solutions}

This table shows the distance between two actions $p$ and $r$ with respect to each criterion calculated using the Hamming distance method. Note that in Table 13, the first number and the second in each cell represent $d\left(\max \left(\tilde{v}_{p j}, \tilde{v}_{r j}\right), \tilde{v}_{r j}\right)$ and $d\left(\max \left(\tilde{v}_{p j}, \tilde{v}_{r j}\right), \tilde{v}_{p j}\right)$, respectively.

Table 13

The distances between any two alternatives $p$ and $r$ with respect to each criterion (for the first six criteria).

\begin{tabular}{cccccccccccc}
$\mathrm{C}_{1}$ & $\mathrm{X}_{11}$ & $\mathrm{X}_{21}$ & $\mathrm{X}_{31}$ & $\mathrm{X}_{41}$ & $\mathrm{X}_{51}$ & $\mathrm{C}_{2}$ & $\mathrm{X}_{12}$ & $\mathrm{X}_{22}$ & $\mathrm{X}_{32}$ & $\mathrm{X}_{42}$ & $\mathrm{X}_{52}$ \\
\hline $\mathrm{X}_{11}$ & - & $(0,0.25)$ & $(0.01,0)$ & $(0,0.25)$ & $(0,0.03)$ & $\mathrm{X}_{12}$ & - & $(0.02,0)$ & $(0.02,0)$ & $(0.13,0)$ & $(0.03,0)$ \\
$\mathrm{X}_{21}$ & - & - & $(0.26,0)$ & $(0,0)$ & $(0.22,0)$ & $\mathrm{X}_{22}$ & - & - & $(0,0)$ & $(0.10,0)$ & $(0.01,0)$ \\
$\mathrm{X}_{31}$ & - & - & - & $(0,0.26)$ & $(0,0.04)$ & $\mathrm{X}_{32}$ & - & - & - & $(0.10,0)$ & $(0.01,0)$ \\
$\mathrm{X}_{41}$ & - & - & - & - & $(0.22,0)$ & $\mathrm{X}_{42}$ & - & - & - & - & $(0,0.10)$ \\
$\mathrm{X}_{51}$ & - & - & - & - & - & $\mathrm{X}_{52}$ & - & - & - & - & - \\
\hline $\mathrm{C}_{3}$ & $\mathrm{X}_{13}$ & $\mathrm{X}_{23}$ & $\mathrm{X}_{33}$ & $\mathrm{X}_{43}$ & $\mathrm{X}_{53}$ & $\mathrm{C}_{4}$ & $\mathrm{X}_{14}$ & $\mathrm{X}_{24}$ & $\mathrm{X}_{34}$ & $\mathrm{X}_{44}$ & $\mathrm{X}_{54}$ \\
\hline $\mathrm{X}_{13}$ & - & $(0,0.05)$ & $(0,0)$ & $(0,0.45)$ & $(0,0.01)$ & $\mathrm{X}_{14}$ & - & $(0,0)$ & $(0,0)$ & $(0,0)$ & $(0.01,0)$ \\
$\mathrm{X}_{23}$ & - & - & $(0.05,0)$ & $(0,0.40)$ & $(0.04,0)$ & $\mathrm{X}_{24}$ & - & - & $(0,0)$ & $(0,0.01)$ & $(0.01,0)$ \\
$\mathrm{X}_{33}$ & - & - & - & $(0,0.45)$ & $(0,0.02)$ & $\mathrm{X}_{34}$ & - & - & - & $(0,0.01)$ & $(0.01,0)$ \\
$\mathrm{X}_{43}$ & - & - & - & - & $(0.44,0)$ & $\mathrm{X}_{44}$ & - & - & - & $(0,0)$ & $(0.01,0)$ \\
$\mathrm{X}_{53}$ & - & - & - & - & - & $\mathrm{X}_{54}$ & - & - & - & $\mathrm{X}_{0}$ \\
\hline $\mathrm{C}_{5}$ & $\mathrm{X}_{15}$ & $\mathrm{X}_{25}$ & $\mathrm{X}_{35}$ & $\mathrm{X}_{45}$ & $\mathrm{X}_{55}$ & $\mathrm{C}_{6}$ & $\mathrm{X}_{16}$ & $\mathrm{X}_{26}$ & $\mathrm{X}_{36}$ & $\mathrm{X}_{46}$ & $\mathrm{X}_{56}$ \\
\hline $\mathrm{X}_{15}$ & - & $(0,0)$ & $(0,0)$ & $(0.01,0)$ & $(0,0)$ & $\mathrm{X}_{16}$ & - & $(0.01,0)$ & $(0,0)$ & $(0.05,0)$ & $(0,0.01)$ \\
$\mathrm{X}_{25}$ & - & - & $(0,0)$ & $(0.01,0)$ & $(0,0)$ & $\mathrm{X}_{26}$ & - & - & $(0,0.02)$ & $(0.04,0)$ & $(0,0.02)$ \\
$\mathrm{X}_{35}$ & - & - & - & $(0.01,0)$ & $(0,0)$ & $\mathrm{X}_{36}$ & - & - & - & $(0.06,0)$ & $(0,0.01)$ \\
$\mathrm{X}_{45}$ & - & - & - & - & $(0,0.01)$ & $\mathrm{X}_{46}$ & - & - & - & - & $(0,0.07)$ \\
$\mathrm{X}_{55}$ & - & - & - & - & - & $\mathrm{X}_{56}$ & - & - & - & - & - \\
\hline
\end{tabular}

Table 14

The concordance matrix.

\begin{tabular}{cccccc}
\hline & \multicolumn{5}{c}{ Alternatives } \\
\cline { 2 - 6 } & $\mathbf{A}_{\mathbf{1}}$ & $\mathbf{A}_{\mathbf{2}}$ & $\mathbf{A}_{\mathbf{3}}$ & $\mathbf{A}_{\mathbf{4}}$ & $\mathbf{A}_{\mathbf{5}}$ \\
\hline $\mathbf{A}_{\mathbf{1}}$ & - & $(4.2,5.4,6.2)$ & $(2.4,2.8,3.0)$ & $(3.6,4.6,5.4)$ & $(3.0,3.9,4.5)$ \\
$\mathbf{A}_{\mathbf{2}}$ & $(4.4,5.6,6.4)$ & - & $(2.8,3.5,3.8)$ & $(3.0,3.8,4.4)$ & $(3.7,4.7,5.4)$ \\
$\mathbf{A}_{\mathbf{3}}$ & $(5.1,6.7,8.0)$ & $(5.3,6.9,8.0)$ & - & $(4.6,6.0,7.1)$ & $(4.6,6.0,7.1)$ \\
$\mathbf{A}_{\mathbf{4}}$ & $(4.5,5.7,6.5)$ & $(5.3,6.7,7.5)$ & $(3.0,3.6,3.9)$ & - & $(3.4,4.2,4.7)$ \\
$\mathbf{A}_{\mathbf{5}}$ & $(4.8,6.2,7.2)$ & $(4.6,6.1,7.1)$ & $(3.0,3.6,3.9)$ & $(4.2,5.4,6.3)$ & - \\
\hline$\tilde{X}$ & $(3.96,5.05,5.80)$ & & & & \\
\hline
\end{tabular}


Table 14 shows the concordance matrix obtained by using Eq. (18). Also Table 15 shows the discordance matrix obtained by using Eq. (21). Boolean matrices $G$ and $H$ are show in Table 16. The global matrix is shown in Table 17.

Table 15

The discordance matrix.

\begin{tabular}{cccccc}
\hline & \multicolumn{5}{c}{ Alternatives } \\
\cline { 2 - 6 } & $\mathbf{A}_{\mathbf{1}}$ & $\mathbf{A}_{\mathbf{2}}$ & $\mathbf{A}_{\mathbf{3}}$ & $\mathbf{A}_{\mathbf{4}}$ & $\mathbf{A}_{\mathbf{5}}$ \\
\hline $\mathbf{A}_{\mathbf{1}}$ & - & 0.18 & 1.00 & 0.28 & 0.82 \\
$\mathbf{A}_{\mathbf{2}}$ & 1.00 & - & 1.00 & 0.26 & 1.00 \\
$\mathbf{A}_{\mathbf{3}}$ & 0.77 & 0.32 & - & 0.28 & 0.57 \\
$\mathbf{A}_{\mathbf{4}}$ & 1.00 & 1.00 & 1.00 & - & 1.00 \\
$\mathbf{A}_{\mathbf{5}}$ & 1.00 & 0.34 & 1.00 & 0.24 & - \\
\hline $\bar{Y}$ & 0.70 & & & & \\
\hline
\end{tabular}

Table 16

Boolean matrices $\mathrm{G}$ and $\mathrm{H}$.

\begin{tabular}{cccccc}
\hline & \multicolumn{5}{c}{ Alternatives } \\
\cline { 2 - 6 } & $\mathbf{A}_{\mathbf{1}}$ & $\mathbf{A}_{\mathbf{2}}$ & $\mathbf{A}_{\mathbf{3}}$ & $\mathbf{A}_{\mathbf{4}}$ & $\mathbf{A}_{5}$ \\
\hline $\mathbf{A}_{\mathbf{1}}$ & - & 1 & 0 & 0 & 0 \\
$\mathbf{A}_{\mathbf{2}}$ & 1 & - & 0 & 0 & 0 \\
$\mathbf{A}_{3}$ & 1 & 1 & - & 1 & 1 \\
$\mathbf{A}_{\mathbf{4}}$ & 1 & 1 & 0 & - & 0 \\
$\mathbf{A}_{5}$ & 1 & 1 & 0 & 1 & - \\
\hline
\end{tabular}

\begin{tabular}{cccccc}
\hline & \multicolumn{5}{c}{ Alternatives } \\
\cline { 2 - 6 } & $\mathbf{A}_{\mathbf{1}}$ & $\mathbf{A}_{\mathbf{2}}$ & $\mathbf{A}_{\mathbf{3}}$ & $\mathbf{A}_{\mathbf{4}}$ & $\mathbf{A}_{\mathbf{5}}$ \\
\hline $\mathbf{A}_{\mathbf{1}}$ & - & 1 & 0 & 1 & 0 \\
$\mathbf{A}_{\mathbf{2}}$ & 0 & - & 0 & 1 & 0 \\
$\mathbf{A}_{\mathbf{3}}$ & 0 & 1 & - & 1 & 1 \\
$\mathbf{A}_{\mathbf{4}}$ & 0 & 0 & 0 & - & 0 \\
$\mathbf{A}_{5}$ & 0 & 1 & 0 & 1 & - \\
\hline
\end{tabular}

(a) G based on the minimum concordance

(b) $\mathrm{H}$ based on minimum discordance level

Table 17

The global matrix.

\begin{tabular}{cccccc}
\hline & \multicolumn{5}{c}{ Alternatives } \\
\cline { 2 - 6 } & $\mathbf{A}_{\mathbf{1}}$ & $\mathbf{A}_{\mathbf{2}}$ & $\mathbf{A}_{\mathbf{3}}$ & $\mathbf{A}_{\mathbf{4}}$ & $\mathbf{A}_{\mathbf{5}}$ \\
\hline $\mathbf{A}_{\mathbf{1}}$ & - & 1 & 0 & 0 & 0 \\
$\mathbf{A}_{\mathbf{2}}$ & 0 & - & 0 & 0 & 0 \\
$\mathbf{A}_{\mathbf{3}}$ & 0 & 1 & - & 1 & 1 \\
$\mathbf{A}_{\mathbf{4}}$ & 0 & 0 & 0 & - & 0 \\
$\mathbf{A}_{5}$ & 0 & 1 & 0 & 1 & - \\
\hline
\end{tabular}

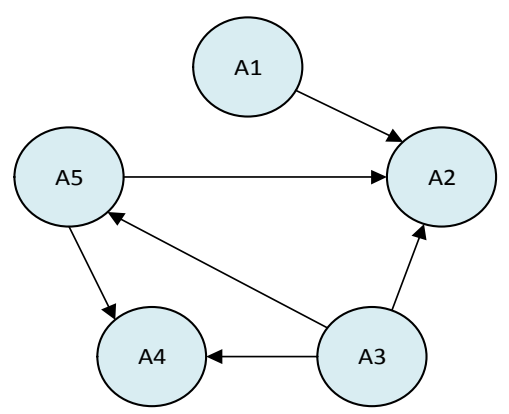

Fig. 4. The decision graph for the numerical example. 
Finally, the decision graph is formed and shown in Fig. 4. As shown in this figure, location $\mathrm{A}_{3}$ is categorized as the first ranking option, because three arcs originate from the nodes $A_{3}$. That means that $A_{3}$ is preferred over $A_{2}, A_{5}$ and $A_{4}$. Moreover, location $A_{5}$ is categorized as the second best option. $A_{2}$ and $A_{4}$ are ranked as the last two locations, because all actions are dominated by $A_{2}$ and $A_{4}$. According to Table $18, A_{3}$ is selected as the best location among five location alternatives for the $\mathrm{CO}_{2}$ storage.

\section{Table 18}

Final ranking.

\begin{tabular}{ccc}
\hline Alternatives & Submissive alternatives & Final ranking \\
\hline $\mathrm{A}_{1}$ & $\mathrm{~A}_{2}$ & 3 \\
$\mathrm{~A}_{2}$ & - & - \\
$\mathrm{A}_{3}$ & $\mathrm{~A}_{2}, \mathrm{~A}_{4}, \mathrm{~A}_{5}$ & 1 \\
$\mathrm{~A}_{4}$ & & - \\
$\mathrm{A}_{5}$ & $\mathrm{~A}_{2}, \mathrm{~A}_{4}$ & 2 \\
\hline
\end{tabular}

\subsection{Fuzzy VIKOR Solutions}

The fuzzy best and worst values are determined using equations (27) and (28) and they are indicated in Table 19 as follows.

\section{Table 19}

Fuzzy best values $\left(\tilde{\mathrm{f}}_{i}^{*}\right)$ and fuzzy worst values $\left(\tilde{\mathrm{f}}_{i}^{-}\right)$.

\begin{tabular}{ccc}
\hline Criteria & $\tilde{f}_{i}^{*}$ & $\tilde{f}_{i}^{-}$ \\
\hline $\mathrm{C}_{1}$ & $(8.00,9.50,10.0)$ & $(3.00,5.00,7.00)$ \\
$\mathrm{C}_{2}$ & $(7.00,8.75,9.75)$ & $(0.75,1.50,3.00)$ \\
$\mathrm{C}_{3}$ & $(7.50,8.75,9.75)$ & $(0.25,1.00,2.50)$ \\
$\mathrm{C}_{4}$ & $(8.00,9.50,10.0)$ & $(3.50,5.50,7.50)$ \\
$\mathrm{C}_{5}$ & $(8.00,9.50,10.0)$ & $(4.50,6.50,8.25)$ \\
$\mathrm{C}_{6}$ & $(7.00,8.75,9.75)$ & $(1.75,3.25,5.00)$ \\
$\mathrm{C}_{7}$ & $(8.00,9.50,10.0)$ & $(5.50,7.50,9.00)$ \\
$\mathrm{C}_{8}$ & $(7.00,8.50,9.25)$ & $(0.25,1.25,3.00)$ \\
$\mathrm{C}_{9}$ & $(6.50,8.25,9.25)$ & $(3.50,5.50,7.25)$ \\
$\mathrm{C}_{10}$ & $(8.00,9.50,10.0)$ & $(1.75,3.50,5.50)$ \\
$\mathrm{C}_{11}$ & $(6.00,8.00,9.50)$ & $(1.25,3.00,5.00)$ \\
$\mathrm{C}_{12}$ & $(8.50,9.75,10.0)$ & $(5.00,7.00,8.50)$ \\
\hline
\end{tabular}


Using equations (29) and (30) the distances of the alternatives to the best and worst values are calculated and they are indicated in Table 20 (a) as follows. $\widetilde{\mathrm{S}}^{*}, \widetilde{\mathrm{S}}^{-}, \widetilde{\mathrm{R}}^{*}$ and $\widetilde{\mathrm{R}}^{-}$values found using equations (31) and (32) and $\widetilde{\mathrm{Q}}_{\mathrm{i}}$ values calculated by being located in its place in the equation (33) are indicated in Table 20 (b).

\section{Table 20}

Index values.

\begin{tabular}{|c|c|c|c|c|}
\hline Alternatives & $\tilde{\mathrm{S}}_{\mathrm{j}}$ & $\widetilde{R}_{j}$ & & Values \\
\hline $\mathrm{A}_{1}$ & $(3.480,4.339,4.748)$ & $(0.800,0.950,1.000)$ & $\operatorname{Min} \tilde{\mathrm{S}}^{*}$ & $(0.546,0.550,0.357)$ \\
\hline $\mathrm{A}_{2}$ & $(5.769,7.030,7.548)$ & $(0.800,0.950,1.000)$ & $\operatorname{Max} \widetilde{S}^{-}$ & $(5.769,7.030,7.548)$ \\
\hline $\mathrm{A}_{3}$ & $(0.546,0.550,0.357)$ & $(0.183,0.234,0.270)$ & $\operatorname{Min} \widetilde{R}^{*}$ & $(0.183,0.234,0.270)$ \\
\hline $\mathrm{A}_{4}$ & $(5.336,6.594,7.129)$ & $(0.850,0.975,1.000)$ & $\operatorname{Max} \widetilde{R}^{-}$ & $(0.850,0.975,1.000)$ \\
\hline $\mathrm{A}_{5}$ & $(3.343,3.651,3.002)$ & $(0.429,0.573,0.583)$ & & \\
\hline
\end{tabular}

(a) $\widetilde{S}_{\mathrm{j}}$ and $\widetilde{\mathrm{R}}_{\mathrm{j}}$

(b) $\widetilde{\mathrm{S}}^{*}, \widetilde{\mathrm{S}}^{-}, \widetilde{\mathrm{R}}^{*}$ and $\widetilde{\mathrm{R}}^{-}$values

Triangular fuzzy numbers are simplified and alternatives are listed according to " $\widetilde{Q}_{i}$ " index. The minimum value of this index indicates the best alternative. Then, the values of $Q_{i}, S_{i}$ and $R_{i}$ in are calculated for alternatives as presented in Table 21.

\section{Table 21}

Ranking of alternatives according to $\mathrm{Q}_{\mathrm{i}}$ index.

\begin{tabular}{|c|c|c|c|c|c|c|c|c|c|}
\hline \multirow{2}{*}{ Alternatives } & \multicolumn{3}{|c|}{$\mathrm{Q}_{\mathrm{i}}$} & \multicolumn{2}{|c|}{$\mathrm{Q}_{\mathrm{i}}$} & \multicolumn{2}{|c|}{$\mathrm{S}_{\mathrm{i}}$} & \multicolumn{2}{|c|}{$\mathrm{R}_{\mathrm{i}}$} \\
\hline & 1 & $\mathrm{~m}$ & $\mathrm{u}$ & Index & Ranking & Index & Ranking & Index & Ranking \\
\hline $\mathrm{A}_{1}$ & 0.74 & 0.78 & 0.81 & 0.77 & 3 & 4.19 & 3 & 0.92 & 3 \\
\hline $\mathrm{A}_{2}$ & 0.96 & 0.98 & 1.00 & 0.98 & 5 & 6.78 & 5 & 0.92 & 3 \\
\hline $\mathrm{A}_{3}$ & 0.00 & 0.00 & 0.00 & 0.00 & 1 & 0.48 & 1 & 0.23 & 1 \\
\hline $\mathrm{A}_{4}$ & 0.96 & 0.97 & 0.97 & 0.97 & 4 & 6.35 & 4 & 0.94 & 4 \\
\hline $\mathrm{A}_{5}$ & 0.45 & 0.47 & 0.40 & 0.44 & 2 & 3.33 & 2 & 0.53 & 2 \\
\hline
\end{tabular}

The ranking of the alternative locations by $\mathrm{Q}_{\mathrm{i}}, \mathrm{S}_{\mathrm{i}}$ and $\mathrm{R}_{\mathrm{i}}$ in decreasing order is shown in Table 22. We can conclude that $A_{3}$ alternative is the best location for $\mathrm{CO}_{2}$ storage; on the other hand, $A_{5}$, $A_{1}, A_{4}$ and $A_{2}$ are less suitable locations than $A_{3}$ alternative.

\section{Table 22}

The ranking of the alternatives.

\begin{tabular}{ll}
\hline & Ranking Alternatives \\
\hline $\mathrm{Q}_{i}$ & $\mathrm{~A}_{3}>A_{5}>A_{1}>A_{4}>A_{2}$ \\
$\mathrm{~S}_{i}$ & $\mathrm{~A}_{3}>A_{5}>A_{1}>A_{4}>A_{2}$ \\
$\mathrm{R}_{i}$ & $\mathrm{~A}_{3}>A_{5}>A_{1}=A_{2}>A_{4}$ \\
\hline
\end{tabular}




\subsection{Comparison of results from the MCDM methods}

The results from the proposed fuzzy methodologies are provided in Table 23. The best location for storing $\mathrm{CO}_{2}$ emissions in Turkey is determined as $A_{3}$ (Diyarbakir) regardless of the fuzzy multi-criteria decision making method used.

Table 23

Result of proposed methodologies.

\begin{tabular}{cccc}
\hline Alternatives & Fuzzy TOPSIS & Fuzzy ELECTRE & Fuzzy VIKOR \\
\hline $\mathrm{A}_{1}$ & 4 & 3 & 3 \\
$\mathrm{~A}_{2}$ & 5 & - & 5 \\
$\mathrm{~A}_{3}$ & 1 & 1 & 1 \\
$\mathrm{~A}_{4}$ & 3 & - & 4 \\
$\mathrm{~A}_{5}$ & 2 & 2 & 2 \\
\hline
\end{tabular}

The ranking of alternatives obtained from fuzzy TOPSIS is $A_{3}>A_{5}>A_{4}>A_{1}>A_{5}$, while $A_{3}>$ $A_{5}>A_{1}$ is obtained by fuzzy ELECTRE, which is a similar result although they are based on different decision schemes. Closeness coefficient is used as a basis for determining the ranking order for TOPSIS. In VIKOR, the aggregate functions are always closest to the ideal values. It is not surprising that ranking result from ELECTRE is similar to VIKOR, since they are based on similar decision schemes which consider maximum group of utility and minimum individual regret. A balance between a maximum group utility of the majority, obtained by concordance that represents the utility measure $S_{i}$ and a minimum of individual regret of the opponent, obtained by discordance that represents the regret measure $R_{i}$ is ensured by the compromise solution of ELECTRE method. However, the computational effort required by ELECTRE is more than the VIKOR method (Anojkumar et al., 2014).

\section{Conclusion}

This study presents the use of fuzzy MCDM methods based on TOPSIS, ELECTRE and VIKOR to assess the suitable location for $\mathrm{CO}_{2}$ storage. A real case example from Turkey is illustrated for evaluating the results of the proposed model by these three methods. Since the three methods that are used for ranking in our problem give similar results, these methods can also give successful results for $\mathrm{CO}_{2}$ location selection. All those methods detects $A_{3}$ (Diyarbakir) as the best alternative for $\mathrm{CO}_{2}$ storage location in Turkey based on the set of criteria. Diyarbakir is also one of the most important cities of Turkey for having finished oil reservoirs and for its geopolitical location. 
The main aim of this study was to investigate how fuzzy TOPSIS, fuzzy ELECTRE I and Fuzzy VIKOR can be utilized to solve the facility location selection problem for $\mathrm{CO}_{2}$ storage. The proposed solutions based on the determined set of criteria are general and reusable; hence, they can be applied to the same problem in other countries than Turkey. It is important to keep in mind that the other multi criteria decision methods (fuzzy AHP, fuzzy ANP, fuzzy PROMETHEE, Fuzzy DEMATEL etc.) and/or their combinations can also be used as effective solutions to the facility location selection problems.

\section{References}

Adams, D., Davison, J., 2007. IEA GHG R\&D Programme: Capturing CO2. ISBN: 978-1898373-41-4.

Akyuz, G., 2012. Supplier selection with fuzzy VIKOR method. Ataturk University/Journal of Economics and Administrative Sciences 26 (1), 197-215.

Alpay, M., 2010. TOPSIS method in evaluation of credit rating and a research. Master Thesis, Dokuz Eylul University, Institute of Social Sciences, Izmir.

Anojkumar, L., Ilangkumaran, M., Sasirekha, V., 2014. Comparative analysis of MCDM methods for pipe material selection in sugar industry. Expert Systems with Applications 41 (6), 29642980.

Ashrafzadeh, M., Rafiei, F. M., Isfahani, N. M., Zare, Z., 2012. Application of fuzzy TOPSIS method for the selection of Warehouse Location: A Case Study. Interdisciplinary Journal of Contemporary Research in Business 3 (9), 655-671.

Awasthi, A., Chauhan, S.S., Goyal, S.K., 2011. A multi-criteria decision making approach for location planning for urban distribution centers under uncertainty. Mathematical and Computer Modelling 53 (1), 98-109.

Badri, M.A., 1999. Combining the analytic hierarchy process and goal programming for global facility location-allocation problem. International Journal of Production Economics 62 (3), 237-248.

Benayoun, R., Roy, B., Sussman, N., 1966. Manual de reference du programme electre, Note de Synthese et Formation. Paris: Direction Scientifique SEMA, vol.25.

Blunt, M., 2010. Carbon dioxide storage. Grantham Institute Briefing paper, 4, pp.1-14.

Chen, C.T., 2000. Extensions of the TOPSIS for group decision-making under fuzzy environment. Fuzzy sets and systems 114 (1), 1-9.

Chen, C.T., Lin, C.T., Huang, S.F., 2006. A fuzzy approach for supplier evaluation and selection in supply chain management. International journal of production economics 102 (2), 289301.

Chou, S.Y., Chang, Y.H., Shen, C.Y., 2008. A fuzzy simple additive weighting system under group decision-making for facility location selection with objective/subjective attributes. European Journal of Operational Research 189 (1), 132-145.

Choudhary, D., Shankar, R., 2012. An STEEP-fuzzy AHP-TOPSIS framework for evaluation and selection of thermal power plant location: A case study from India. Energy 42 (1), 510-521.

Chu, C.T., 2002. Facility location selection using fuzzy TOPSIS under group decisions, Int. J. of Uncertain, Fuzziness and Knowledge-Based Systems 10 (06), 687-701. 
Davison, J., 2007. Performance and costs of power plants with capture and storage of CO2, Energy 32 (7), 1163-1176.

Demirel, T., Demirel, N.C., Kahraman, C., 2010. Multi-criteria warehouse location selection using Choquet integral. Expert Systems with Applications 37 (5), 3943-3952.

Devi, K., Yadav, S. P., 2013. A multicriteria intuitionistic fuzzy group decision making for plant location selection with ELECTRE method. The International Journal of Advanced Manufacturing Technology 66 (9-12), 1219-1229.

Ersoy, A., Saat Ersoy, M., 2008. Production/ Operations Management. 2.Edition, Imaj Press., Ankara.

Ertugrul, I., Karakasoglu, N., 2008. Comparison of fuzzy AHP and fuzzy TOPSIS methods for facility location selection. The Int. J. Adv. Manuf. Technol. 39 (7-8), 783-795.

Feron, P., Paterson, L., 2011. Reducing the costs of CO2 capture and storage (CCS). Report edition, CSIRO, 1-16, doi: http://www.garnautreview.org.au/update-2011/commissionedwork/reducing-costs-CO2-capture-storage.pdf (last access in Jan 2015).

Fetanat, A., Khorasaninejad, E., 2015. A novel hybrid MCDM approach for offshore wind farm site selection: A case study of Iran. Ocean \& Coastal Management 109, 17-28.

Grataloup, S., et al., 2009. Thoraval, A site selection methodology for $\mathrm{CO}_{2}$ underground storage in deep saline aquifers: case of the Paris Basin. Energy Procedia 1 (1), 2929-2936.

Hamming, R.W., 1950. Error detecting and error correcting codes. Bell System Technical J. 29 (2), 147-160.

Hatami-Marbini, A., Tavana, M., 2011. An extension of the Electre I method for group decisionmaking under a fuzzy environment. Omega 39 (4), 373-386.

Hatami-Marbini, A., Tavana, M., Moradi, M., Kangi, F., 2013. A fuzzy group Electre method for safety and health assessment in hazardous waste recycling facilities. Safety science 51 (1), 414-426.

Hsieh, T.Y., Lu, S.T., Tzeng, G.H., 2004. Fuzzy MCDM approach for planning and design tenders selection in public office buildings. International journal of project management 22 (7), 573-584.

Hsu, C.W., Chen, L.T., Hu, A.H., Chang, Y.M., 2012. Site selection for carbon dioxide geological storage using analytic network process. Separation and Purification Technology 94, 146-153.

Hu, Y., Wu, S., Cai, L., 2009. Fuzzy multi-criteria decision-making TOPSIS for distribution center location selection, in: Proceedings of the International Conference on Networks Security, Wireless Communications and Trusted Computing, vol.2, pp.707-710.

Hwang, C.L., Yoon, K., 1981. Multiple attributes decision making methods and applications. Springer, Berlin Heidelberg.

IEA (International Energy Agency) World Energy Outlook 2004, <http://www.worldenergyoutlook.org/media/weowebsite/2008-1994/weo2004.pdf > (last access in Jan 2015).

Ka, B., 2011. Application of fuzzy AHP and ELECTRE to China dry port location selection. The Asian Journal of Shipping and Logistics 27 (2), 331-353.

Kabir, G., Sumi, R. S., 2014. Power substation location selection using fuzzy analytic hierarchy process and PROMETHEE: A case study from Bangladesh. Energy 72, 717-730. 
Kaboli, A., Aryanezhad, M.B., Shahanaghi, K., Niroomand, I., 2007. A new method for plant location selection problem: a fuzzy-AHP approach, in: Proceedings of the Systems, Man and Cybernetics, pp.582-586.

Kahraman, C., Ruan, D., Dogan, I., 2003. Fuzzy group decision-making for facility location selection. Information Sciences 157, 135-153.

Kissinger, A., et al., 2014. Characterization of reservoir conditions for $\mathrm{CO} 2$ storage using a dimensionless Gravitational Number applied to the North German Basin. Sustainable Energy Technologies and Assessments 7, 209-220.

Liao, C., et al., 2014. Comparison of different methods for determining key parameters affecting $\mathrm{CO}_{2}$ storage capacity in oil reservoirs. International Journal of Greenhouse Gas Control 28, 25-34.

Llamas, B., Camara, A., 2014. Application of multicriteria algorithm to select suitable areas for storing CO2: CO2 Site Assess software. Energy Procedia 63, 4977-4986.

Llamas, B., Cienfuegos, P., 2012. Multicriteria decision methodology to select suitable areas for storing CO2. Energy \& Environment 23 (2-3), 249-264.

Momeni, M., Fathi, M.R. Kashef, M., 2011. A fuzzy VIKOR approach for plant location selection. Journal of American Science 7 (9), 766-771.

Nazari, A., Salarirad, M. M., Bazzazi, A. A., 2012. Landfill site selection by decision-making tools based on fuzzy multi-attribute decision-making method. Environmental Earth Sciences 65 (6), 1631-1642.

Opricovic, S., 1998. Multicriteria optimization of civil engineering systems. Faculty of Civil Engineering 2 (1), 5-21.

Opricovic, S., Tzeng, G.H., 2004. Compromise solution by MCDM methods: A comparative analysis of VIKOR and TOPSIS. European Journal of Operational Research 156 (2), 445455.

Opricovic, S., 2011. Fuzzy VIKOR with an application to water resources planning. Expert Systems with Applications 38 (10), 12983-12990.

Ozdagoglu, A., 2011. A multi-criteria decision-making methodology on the selection of facility location: fuzzy ANP. The Int. J. of Advanced Manufacturing Technology 59 (5-8), 787-803.

Panigrahi, S., 2014. Fuzzy-TOPSIS for Appropriate Site Selection for Establishing a Thermal Power Plant (Doctoral dissertation). PhD thesis, National Institute of Technology Rourkela 769008, INDIA.

Ramirez, A., et al., 2010. Screening CO2 storage options in the Netherlands. International Journal of Greenhouse Gas Control 4 (2), 367-380.

Rezaei, P., Rezaie, K., Nazari-Shirkouhi, S., Tajabadi, M. R. J., 2013. Application of Fuzzy Multi-Criteria Decision Making Analysis for Evaluating and Selecting the Best Location for Construction of Underground Dam. Acta Polytechnica Hungarica 10 (7), 187-205.

Rouyendegh, B.D., Erkan, T.E., 2013. An application of the fuzzy electre method for academic staff selection. Human Factors and Ergonomics in Manufacturing \& Service Industries 23 (2), 107-115.

Sahin, S., Kalfa, U., Celebioglu, D., Duygu, E., Lahna, H., 2012. A auarter century of progress in the application of $\mathrm{CO}_{2}$ immiscible EOR project in Bati Raman Heavy Oil Field in Turkey. In SPE Heavy Oil Conference Canada. Society of Petroleum Engineers, pp.1-14, doi: http://dx.doi.org/10.2118/157865-MS. 
Sanchez-Lozano, J. M., Garcia-Cascales, M. S., Lamata, M. T., 2015. Evaluation of suitable locations for the installation of solar thermoelectric power plants. Computers \& Industrial Engineering 87, 343-355.

Stasa, P., et al., 2013. Research of $\mathrm{CO}_{2}$ storage possibilities to the underground. Procedia Earth and Planetary Science 6, 14-23.

Sunjay, S., Singh, V.K., 2010. Geological storage: underground gas storage, in: Proceeding of the 8th Biennial International Conference \& Exposition on Petroluem Geophysics (HYDERABAD), pp.1-7.

Tre, D.G., Dujmovic, J. J., Bronselaer, A., Matthe, T., 2011. Quantifier based aggregation in LSP suitability map construction: in Proceedings of the World Conference on Soft Computing, edited by RR Yager, MZ Reformat, SN Shahbazova and S. Ovchinnikov, vol. 111, pp. 1-8.

Ulukan, H.Z., Kop, Y., 2009. A two-step solution procedure to a fuzzy medical waste disposal facility location problem, in: Proceedings of the Joint 2009 International Fuzzy Systems Association World Congress and 2009 European Society of Fuzzy Logic and Technology Conference (IFSA/EUSFLAT), pp.1450-1455.

Verma, A. K., Verma, R., Mahanti, N. C., 2010. Facility location selection: an interval valued intuitionistic fuzzy TOPSIS approach. Journal of Modern Mathematics and Statistics 4 (2), 68-72.

Wu, Y., Geng, S., Zhang, H., Gao, M., 2014. Decision framework of solar thermal power plant site selection based on linguistic Choquet operator. Applied Energy 136, 303-311.

Yong, D., 2006. Plant location selection based on fuzzy TOPSIS. The International Journal of Advanced Manufacturing Technology 28 (7-8), 839-844.

Zadeh, L.A., 1965. Fuzzy sets. Information and control 8 (3), 338-353.

Zandi, A., Roghanian, E., 2013. Extension of Fuzzy ELECTRE based on VIKOR method. Computers \& Industrial Engineering 66 (2), 258-263. 